\title{
THE EFFECTS OF CELEBRITY ENDORSER AUTHENTICITY AND PRODUCT CONGRUENCE ON BRAND EXPERIENCE
}

CATHERINE CRUIKSHANK

May 7, 2018

Submitted in partial fulfillment of the requirements for Departmental Honors in the Department of Marketing

Texas Christian University Fort Worth, Texas 


\section{ABSTRACT:}

The purpose of this study is to observe the impact of celebrity endorser authenticity and product congruence on brand experience, brand evaluations and celebrity evaluations. Celebrity authenticity is de ined by the celebrity's ability to demonstrate rarity and stability, or their ability to maintain unique characteristics and talents consistently across time and situation. Congruence is how well a celebrity endorser matches with the brand's product or product category. Previous studies suggest that both of these constructs independently enhance brand evaluations, such as brand loyalty, positive word of mouth and emotional connection. In this case, authenticity and congruence were observed together. To test whether authenticity and congruence jointly impacted brand experience, brand evaluations, and celebrity evaluations, an experiment was conducted. In order to ensure internal validity, known brands and known celebrities were not used. Instead, a vignette approach was utilized. I found that, overall, authentic and congruent endorsement independently produced the strongest brand experience and the strongest evaluations. Authenticity and congruence together did not produce a synergistic effect but independently, when a celebrity endorser was authentic versus not authentic, evaluations were better and when a celebrity was congruent versus incongruent, evaluations were better. Therefore, in conclu-sion, if brand managers are looking to enhance brand experience or brand evaluations through celebrity endorsement, it is best to hire a celebrity that is authentic and a celebrity that is aligned with the brand's product or product category. Additionally, if looking to enhance the evaluations of their currently con-tracted celebrity endorsers, perceived authenticity signi icantly impacts these evaluations. An overar-ching insight this study demonstrates, however, is that in an age of excess use of technology and social media where information is more readily available, it is important for companies to look beyond just profession when determining the best endorsement candidate to hire. 


\section{TABLE OF CONTENTS:}

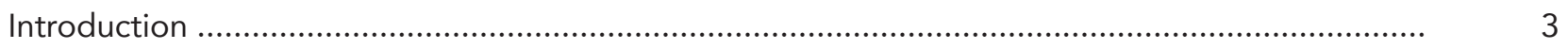

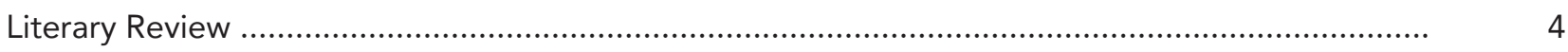

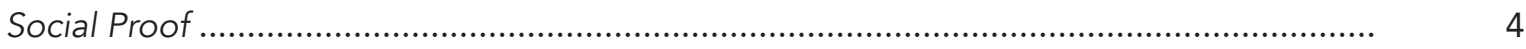

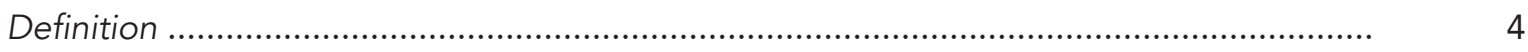

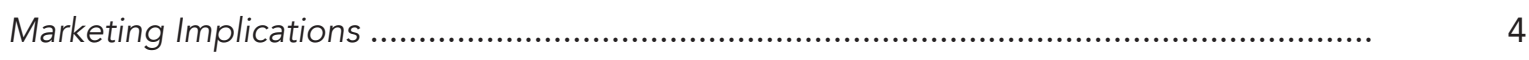

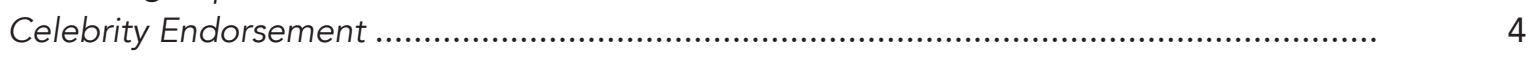

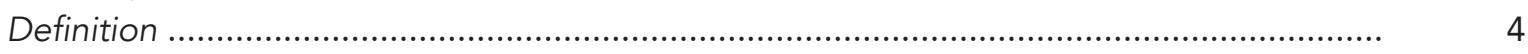

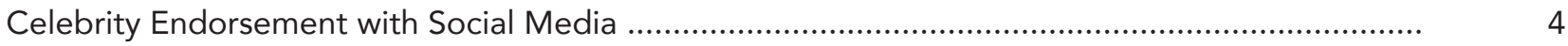

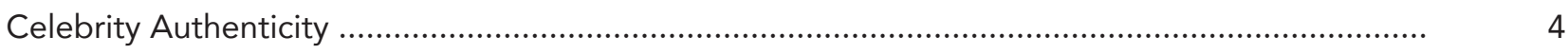

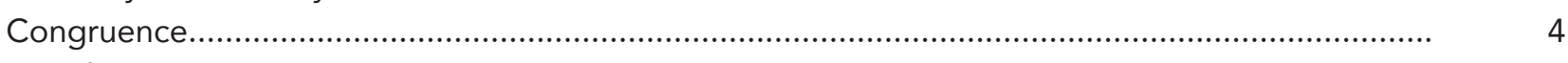

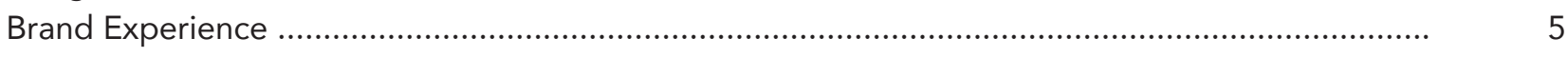

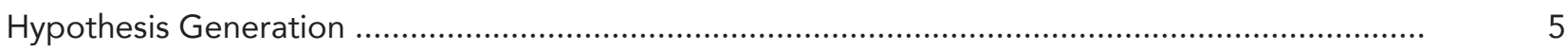

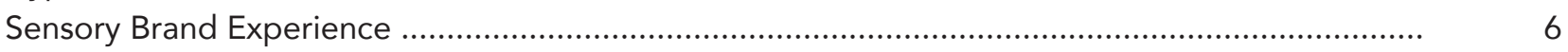

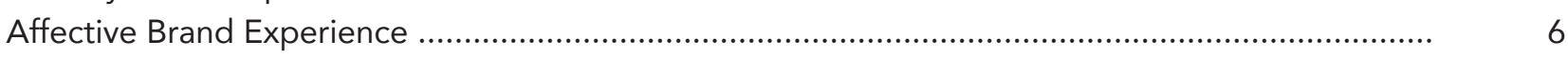

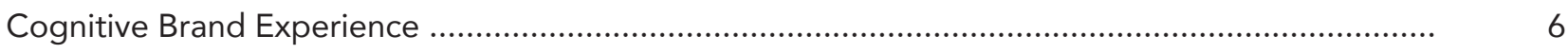

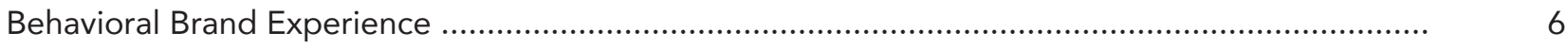

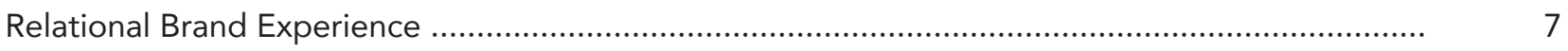

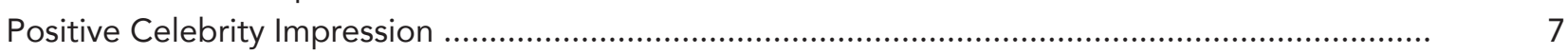

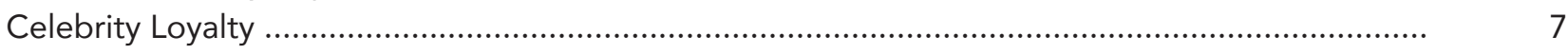

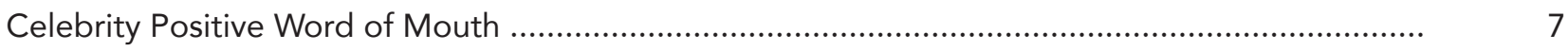

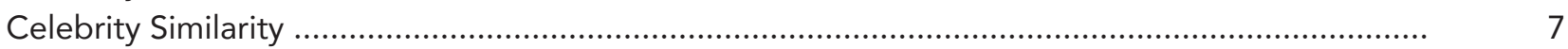

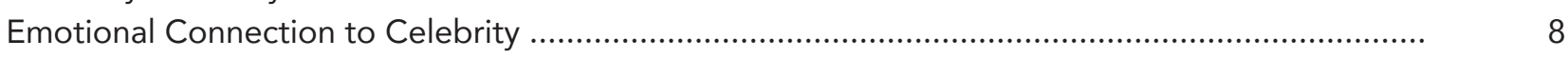

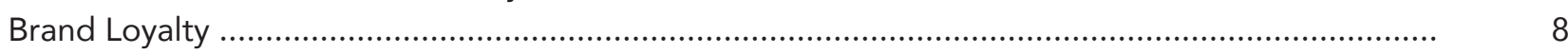

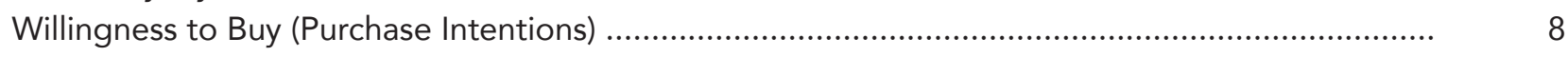

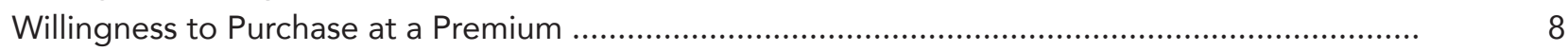

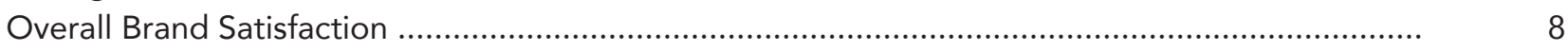

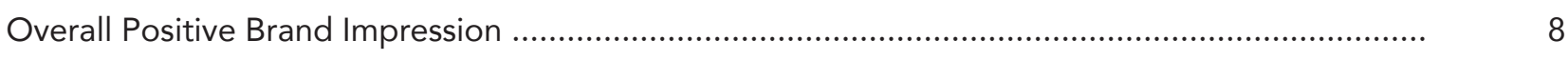

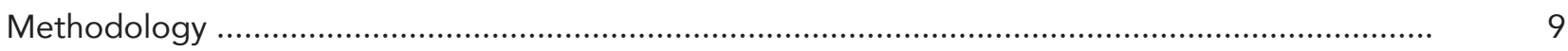

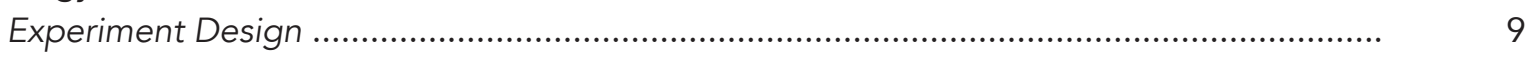

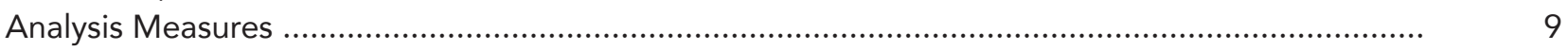

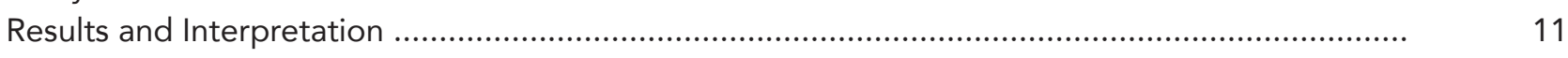

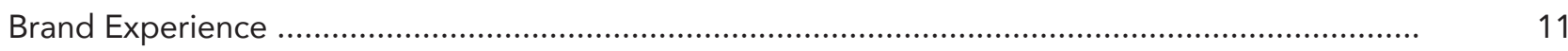

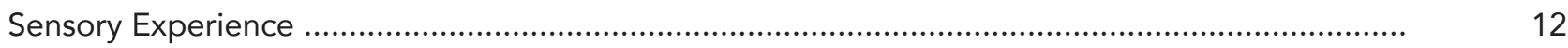

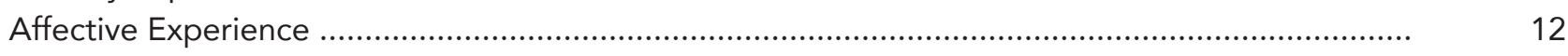

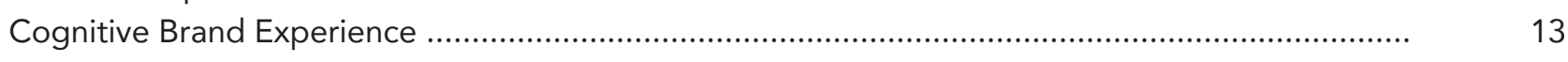

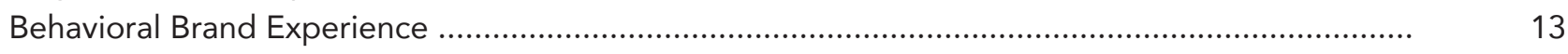

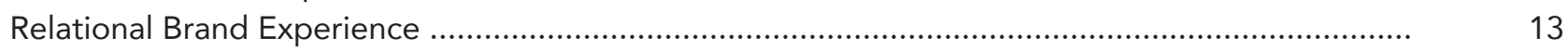

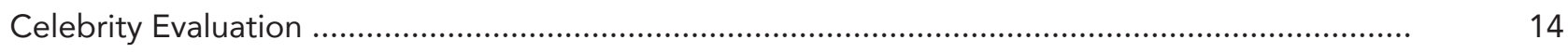

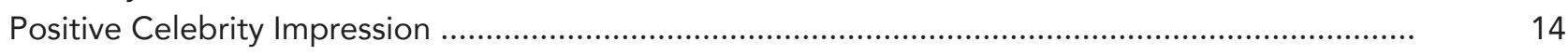

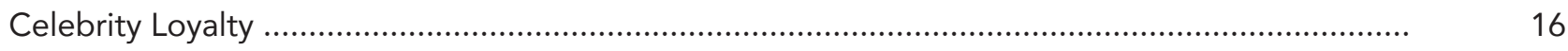




\section{TABLE OF CONTENTS:}

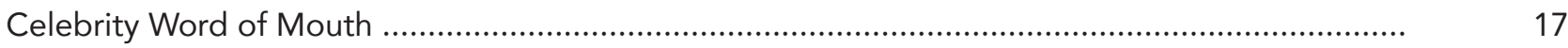

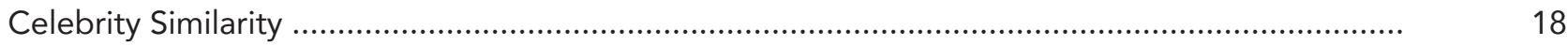

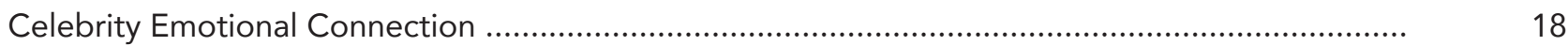

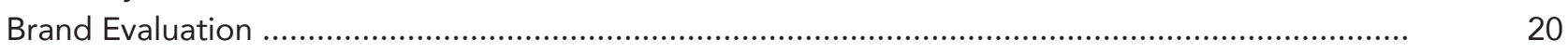

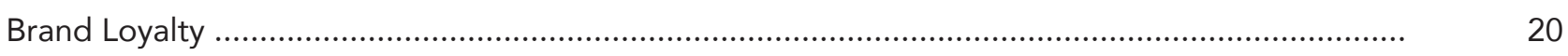

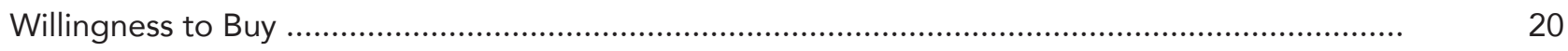

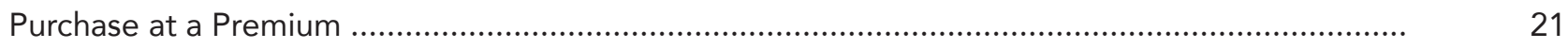

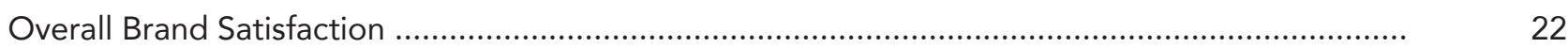

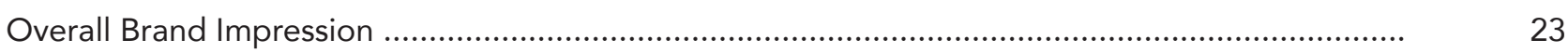

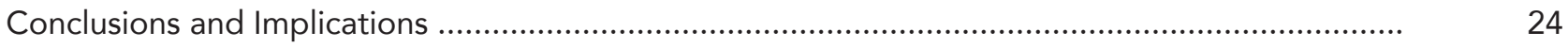

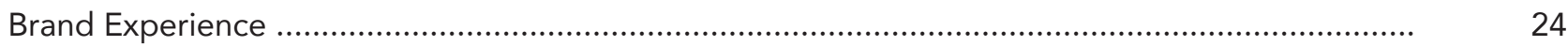

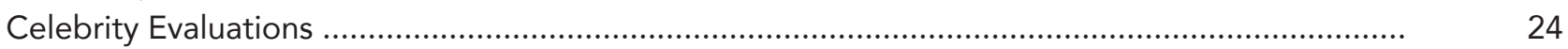

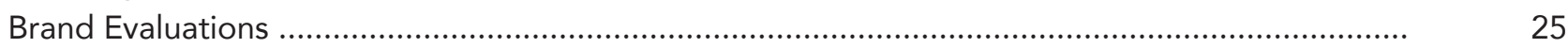

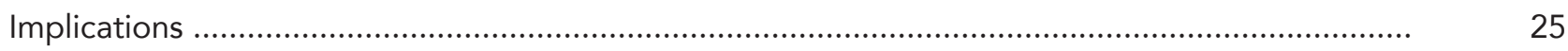

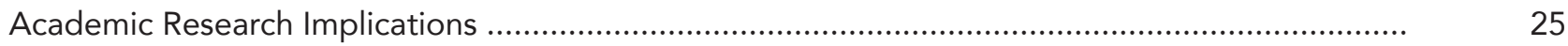

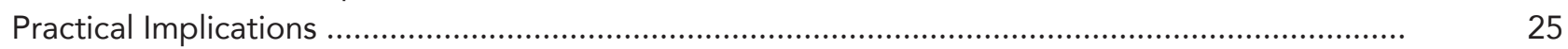

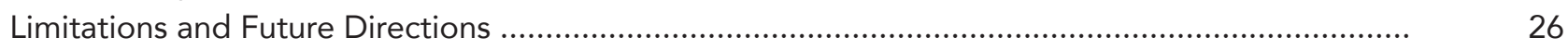

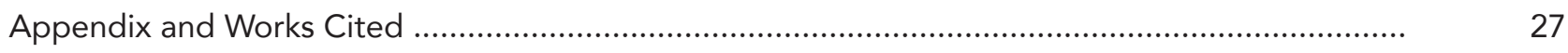

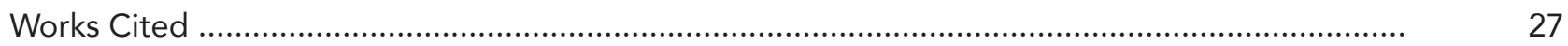

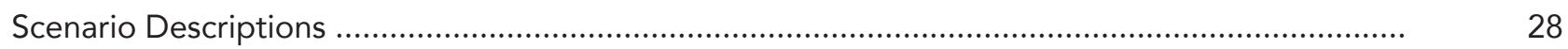

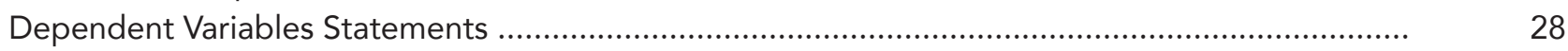




\section{Introduction}

Consumer decisions are implicitly impacted by social influence, or surrounding people and social constructs. People often seek out social validation from others throughout the decision-making process (Cialdini, 2006). This implicit tendency has only been amplified with recent technological advancement, such as social media. Social media and other information networks that have emerged in recent years have allowed the consumer market to move from individual to increasingly social. This means consumers are now able to be active participants in marketing endeavors, rather than passive bystanders of marketing influences (Kotler et al, 2016). Therefore, people are relying more heavily on others, whether that be family, friends or even stranger referrals, rather than their own judgments or direct marketing content received from companies directly to make decisions (Kotler et al, 2016). This has sparked wide-spread influencer marketing and changes in the methods in which products are endorsed.

Although celebrity endorsement has been used for decades, today's consumer market has the ability to access more in-depth personal and career information about celebrities (Kowalczyk \& Pounders, 2016). Especially as celebrities engage on social media, every-day consumers have a direct and immediate access to any given celebrity. Therefore, marketers are no longer able to completely safeguard celebrity reputations. This creates a unique challenge for marketers utilizing endorsement since the core idea behind celebrity endorsement is that the unique value the celebrity holds will transcend to the brand (Choi \& Rifon, 2012). Previous research related to celebrity source credibility argues that three components determine whether a celebrity is deemed credible: expertise, trustworthiness, and attractiveness (Ohanian, 1991). However, with the increased transparency between consumers and celebrities, a new and important dimension for building credibility has emerged: authenticity or staying true to oneself. Authenticity is becoming a more important characteristic to consider when utilizing endorsement. Recent studies have found that authenticity can be measured by rarity and stability (Moulard et al, 2015). Rather, a celebrity is more authentic if they bring unique attributes consistently over time. When looking at a celebrity's social media use, these authenticity measures positively influence WOM and purchase intention (Kowalczyk \& Pounders, 2016). Therefore, consumers are noticing and demanding consistently unique experiences from the celebrities they follow. Similarly, there is an increasing demand for companies to create consistent and unique brand experiences that occur at every stage of the consumer decision-making process (Brakus et al, 2009). The same advancements in social media and technology that give consumers more access to celebrities give brands more access to customers at every step along the decision-making process, making brand interactions more personalized and experience-oriented (Kotler et al, 2016). As authentic experiences are requested from both brands and celebrities themselves, there is a need to observe whether the authentic experience of a celebrity transcends in the endorsement of a brand.

This thesis will observe if perceived authenticity of a celebrity endorser positively contributes to brand experience. Previous research has observed the effect of celebrity endorsement on brand attitudes and purchase intentions but has not observed how authentic celebrity endorsement affects brand experience antecedents including sensory, cognitive, behavioral, emotional and relational factors. This research will additionally observe whether the celebrity's perceived authenticity contributes differently to brand experience if the product is congruent versus not congruent to the celebrity's personal brand. Although there have been studies linked to authenticity positively impacting WOM and purchase intention of the celebrity, they fail to observe whether congruence with the product enhances or diminishes this positive impact. This thesis will help researchers better understand the weight of authenticity in an endorsement deal and whether authenticity outweighs the effects of congruency. It will help practitioners better leverage endorsement deals based on brand experience goals in an age of technological advancement in which consumers have the opportunity to understand celebrities at a deeper, more personal level and brands have less control over celebrity reputation. 


\section{Literary Review \\ Social Proof \\ Definition}

Due to technological advancements, the world runs at a much faster pace today than in the past. Consumers have access to more people, information, and goods than ever before; at the touch of their fingers and at any moment in time. However, the fast-paced nature of our society does not allow us to make all decisions thoughtfully (Cialdini, 2006). Consumers are forced to use heuristics, or mental shortcuts to make decisions. Reliance on these heuristics leave opportunity for marketers to subconsciously influence consumers towards certain buying decisions (Cialdini, 2006). One of these innate psychological heuristics behind buying behavior is social proof. This phenomenon can be defined as "view[ing] a behavior as correct in a given situation to the degree that we see others performing it" (Cialdini, 2006). When people are unsure about a situation or decision, they seek guidance from those around them to identify their behavior as correct (Cialdini, 2006). Additionally, this effect is more intensive when observing people we associate as similar to ourselves (Cialdini, 2006).

\section{Marketing Implications}

Social proof works similarly in a buying context. Consumers look to other consumers for validation and guidance towards "correct" buying behavior (Kotler et al, 2016). Additionally, this search for social validation is amplified when people are looking to those similar or aspirational to themselves. With the rise of social media and other information sharing sites, consumers have increased access to both similar and aspirational people, such as celebrities. This has caused consumers to rely much more heavily on the advice of family, friends, and referrals of celebrities to make decisions rather than traditional marketing communications from companies or even their own judgment (Kotler et al, 2016). This presents a challenge for brands and marketing communications professionals. It is necessary to be strategic in the way brands build trust and credibility with consumers, as consumers have more power to project brand experiences and opinions to the general public (Booth \& Matic, 2011). One way brands have built trust and credibility in the past is through celebrity endorsement. However, as there is more transparent information available to consumers about both celebrities and brands, an increasingly important component of building trust and credibility is authenticity.

\section{Celebrity Endorsement}

Definition

Celebrity endorsement is when a recognized individual promotes a particular product, product feature or brand (Friedman, 1979). In this promotion, the goal is for the value derived from the celebrity's brand to transfer to the product or brand and build trust with consumers that identify with the celebrity (Choi \& Rifon, 2012). In other words, endorsement is a way for consumers to gain social affirmation when purchasing a particular product or choosing a brand. Celebrity endorsement has been used for many years. Traditionally, the positive effects of celebrity endorsement have been explained by theories such as social credibility. Celebrity source credibility theory suggests the antecedents that make celebrity endorsement credible are expertise, trustworthiness and attractiveness (Ohanian, 1991). In today's society where people have access to transparent information about celebrities, such as what they like to do on the weekends or the types of foods they enjoy eating, there is more opportunity for celebrities' to demonstrate expertise beyond their professional field. Additionally, this dynamic creates a desire for authenticity, or the ability for the celebrity to remain true to their values. It is becoming more important when consumers evaluate trustworthiness. Research also suggests that congruence between a celebrity's human brand and consumer's ideal self-concept positively impacts purchase intention (Choi \& Rifon, 2012). This suggests that the effects of authenticity could be stronger if consumers identify as authentic themselves. 
There are four main types of endorsements: explicit, implicit, imperative and co-presentational (Raluca, 2012). Explicit endorsement is when the celebrity outwardly endorses a product, implicit endorsement is when the celebrity uses a product, imperative endorsement is when the celebrity demands others to use a product and co-presentational endorsement is when a celebrity merely appears with a product, which can also be defined as product placement (Raluca, 2012). For the purpose of this study, explicit endorsement will be studied as it is the oldest form of endorsement and can be easily replicated in a controlled experiment.

\section{Celebrity Endorsement with Social Media}

With the rise of social media platforms, consumers have the ability to make a direct connection with celebrities (Kowalczyk \& Pounders, 2016). Communication about celebrity figures is no longer passive, but rather active. Celebrities are able to provide in-depth information about their personal lives and careers at any given time; and consumers seek to obtain this information (Kowalczyk \& Pounders, 2016). This heavy knowledge of celebrity personalities, likes and dislikes, and peaks and valleys, changes the dynamic of the celebrity-brand relationship (Kelting \& Rice, 2013). This shift causes consumers to demand authenticity and emotional attachment from the celebrity, particularly from the celebrity's social media activity (Kowalczyk \& Pounders, 2016).

\section{Celebrity Authenticity}

Celebrity authenticity is defined as "the perception that a celebrity behaves according to his or her true self" (Moulard et al. 2015). Authenticity is a socially constructed phenomenon that is developed from a collection of observations and evaluations from others (Grayson \& Martinec, 2004). Therefore, it is subjectively defined based on the per-

ception of others. Furthermore, the level of authenticity perceived may differ from person to person. However, research suggests that authenticity can be measured by two main factors: rarity and stability (Moulard et al. 2015). Rarity is defined as "the degree to which the celebrity is seen as uncommon" and stability is defined as "the degree to which the celebrity is perceived as unwavering" (Moulard et al. 2015). Additionally, antecedents to perceived celebrity authenticity include celebrities being consistent and open about their values and portraying these values in the ways they interact with others (Ilicic, 2016). Celebrity authenticity through social media has shown to positively affect word of mouth and purchase intention of endorsed products (Kowalczyk \& Pounders, 2016). However, perceived authenticity is diminished if endorsed products or obvious product placement appears too frequently on a celebrity's personal social media accounts (Kowalczyk \& Pounders, 2016).

\section{Congruence}

The match-up hypothesis examines the congruence between celebrity and product (Kahle \& Homer, 1985). The core idea of this principal is that a celebrity endorser is more effective when promoting a product congruent with their profession or expertise. Traditionally, congruence has been defined by self-congruence or brand-congruence. Self-congruence is the degree to which a product is congruent with a consumer's self-image (Jamal \& Goode, 2001). Higher self-congruence has, in previous research, resulted in more brand satisfaction (Jamal \& Goode, 2001). Brand-congruence is defined as the similarity between a celebrity and brand (Misra \& Beatty, 1990). Increased brand congruence is shown to enhance recall and effect on consumers (Misra \& Beatty, 1990). Celebrity endorsers play a role in both self and brand congruence. As people often compare celebrities to their aspirational selves, the celebrity's association with the brand is an important element when brands are building self-congruence with customers. Additionally, having brand congruence suggests celebrities have a direct and noticed connection to the brand. Additionally, research has discovered that celebrity-brand and brand-user personality congruence has a positive impact on purchase intentions and attitudes (Pradhan et al, 2016). This is an important aspect to note as authenticity is a measure of personality. 
Although celebrity-brand congruence has traditionally been seen as a positive antecedent to brand attitude, recent research has discovered that, rather, high congruence and high incongruence advertisements are effective while moderate congruence is not significantly effective (Kelting \& Rice, 2013). This suggests that high congruence continues to positively impact brand attitudes and purchase intentions, but low congruence can appeal to consumers in a different, yet intellectually stimulating way. For example, Carl's Jr.'s campaign in 2005 portrayed Paris Hilton, a thin, physically fit celebrity with fast food that is typically associated high fat and unhealthy habits (YouTube, 2015). Therefore, in this study, it was important to test both high congruence and high incongruence to see whether this phenomenon holds true when consumers are primed with authenticity.

\section{Brand Experience}

As there is increased demand for celebrities to portray a unique and consistent personal brand, there also is increased demand for brands to create a unique and consistent experience. Brand experience contains four main components: sensory, behavioral, affective and intellectual (Brakus, 2009). Sensory experience refers to stimuli contributing to a consumer's five senses-touch, taste, smell, sight and hearing (Brakus, 2009). Behavioral experience refers to the brand's ability to evoke behavior when utilizing a product (Brakus, 2009). Affective experiences encourage consumers to have an emotional connection to the brand (Brakus, 2009). Intellectual experiences challenge consumers to think intellectually (Brakus, 2009). However, research conducted by Nysveen identifies a fifth component to brand experience: relational (Nysveen, 2014). Consumers now expect brands to engage with them in a deep, relational and actively communicative way. Brands can leverage this expectation by more effectively using social media, in particularly celebrity social media platforms, to enhance brand experience. Brand experience has direct impact on customer satisfaction as well as brand loyalty (Brakus 2009, Nysveen 2014). Similarity is a crucial component to building any connection, experience or customer base. Research demonstrates that brand similarity as well as reciprocal liking contributes to positive brand attitude (Harding \& Humphreys, 2010). As a consumer feels similarities between celebrities, there is an opportunity for brands to leverage this connection with endorsement.

\section{Hypothesis Generation}

Based on the above literary review, previous studies have revealed that, in general, celebrity authenticity and celebrity product congruence enhance endorsement effectiveness. Although previous research has studied celebrity authenticity and congruence independently, no studies have looked at the two components interdependently. Ad-ditionally, although previous literature has observed these constructs in relation to general celebrity evaluation and brand evaluation, no literature has evaluated how these two constructs (authenticity and congruence) effect brand experience. Therefore, I hypothesize the following results for all dependent variables. In summary, I hypothesize that there will be a main effect of authenticity. This means that I hypothesize respondents exposed to the authen-tic (A) condition will score each dependent variable significantly higher than those exposed to the not authentic condition (NA). I also hypothesize that there will be a main effect of congruence. This means that I hypothesize respondents exposed to the congruent product (C) will score each dependent variable significantly higher than those exposed to the not congruent product (NC). I also hypothesize there will be an interaction effect between au-thenticity and congruence meaning those exposed to both the authentic and congruent product conditions $\left(A^{\star} C\right)$ will score each dependent variable significantly higher than those exposed to another combination of conditions $\left(A^{\star} N C, N A^{\star} C, N A^{\star} N C\right)$. The following hypothesis statements demonstrate my hypothesis for each dependent variable, specifically. 


\begin{tabular}{|l|l|}
\hline \multicolumn{2}{|c|}{ Key } \\
\hline A & Authenticity Manipulation \\
\hline C & Congruence Manipulation \\
\hline
\end{tabular}

\begin{tabular}{|c|l|l|}
\hline H & \multicolumn{1}{|c|}{ Effect } & \multicolumn{1}{c|}{ Hypothesis Statement } \\
\hline 0.1 & M: A & The dependent variable will be higher for authentic celebrity endorsement. \\
\hline 0.2 & M: C & $\begin{array}{l}\text { The dependent variable will be higher for celebrity endorsement of a } \\
\text { congruent product. }\end{array}$ \\
\hline 0.3 & I: A*C & $\begin{array}{l}\text { The dependent variable will be highest for authentic celebrity endorsement } \\
\text { of a congruent product. }\end{array}$ \\
\hline
\end{tabular}

Sensory Brand Experience:

\begin{tabular}{|c|l|l|}
\hline H & Effect & \multicolumn{1}{c|}{ Hypothesis Statement } \\
\hline 1.1 & M: A & $\begin{array}{l}\text { Sensory brand experience will be higher for authentic celebrity } \\
\text { endorsement. }\end{array}$ \\
\hline 1.2 & M: C & $\begin{array}{l}\text { Sensory brand experience will be highest for celebrity endorsement of a } \\
\text { congruent product. }\end{array}$ \\
\hline 1.3 & I: A*C & $\begin{array}{l}\text { Sensory brand experience will be highest for authentic celebrity } \\
\text { endorsement of a congruent product. }\end{array}$ \\
\hline
\end{tabular}

\section{Affective Brand Experience:}

\begin{tabular}{|c|l|l|}
\hline H & \multicolumn{1}{|c|}{ Effect } & \multicolumn{1}{c|}{ Hypothesis Statement } \\
\hline 2.1 & M: A & $\begin{array}{l}\text { Affective brand experience will be highest for authentic celebrity } \\
\text { endorsement. }\end{array}$ \\
\hline 2.2 & M: $\mathrm{C}$ & $\begin{array}{l}\text { Affective brand experience will be highest for celebrity endorsement of a } \\
\text { congruent product. }\end{array}$ \\
\hline 2.3 & I: $\mathrm{A}^{* \mathrm{C}}$ & $\begin{array}{l}\text { Affective brand experience will be highest for authentic celebrity } \\
\text { endorsement of a congruent product. }\end{array}$ \\
\hline
\end{tabular}

\section{Cognitive Brand Experience:}

\begin{tabular}{|c|l|l|}
\hline H & Effect & \multicolumn{1}{c|}{ Hypothesis Statement } \\
\hline 3.1 & M: A & $\begin{array}{l}\text { Cognitive brand experience will be highest for authentic celebrity } \\
\text { endorsement. }\end{array}$ \\
\hline 3.2 & M: C & $\begin{array}{l}\text { Cognitive brand experience will be highest for celebrity endorsement of a } \\
\text { congruent product. }\end{array}$ \\
\hline 3.3 & I: A*C & $\begin{array}{l}\text { Cognitive brand experience will be highest for an authentic celebrity } \\
\text { endorsement of a congruent product. }\end{array}$ \\
\hline
\end{tabular}

\section{Behavioral Brand Experience:}

\begin{tabular}{|c|l|l|}
\hline H & \multicolumn{1}{|c|}{ Effect } & \multicolumn{1}{c|}{ Hypothesis Statement } \\
\hline 4.1 & M: A & $\begin{array}{l}\text { Behavioral brand experience will be highest for authentic celebrity } \\
\text { endorsement. }\end{array}$ \\
\hline 4.2 & M: C & $\begin{array}{l}\text { Behavioral brand experience will be highest for celebrity endorsement of a } \\
\text { congruent product. }\end{array}$ \\
\hline 4.3 & I: $\mathrm{A}^{*} \mathrm{C}$ & $\begin{array}{l}\text { Behavioral brand experience will be highest for an authentic celebrity } \\
\text { endorsement of a congruent product. }\end{array}$ \\
\hline
\end{tabular}




\section{Relational Brand Experience:}

\begin{tabular}{|c|l|l|}
\hline H & \multicolumn{1}{|c|}{ Effect } & \multicolumn{1}{c|}{ Hypothesis Statement } \\
\hline 5.1 & M: A & $\begin{array}{l}\text { Relational brand experience will be highest for authentic celebrity } \\
\text { endorsement. }\end{array}$ \\
\hline 5.2 & M: C & $\begin{array}{l}\text { Relational brand experience will be highest for celebrity endorsement of a } \\
\text { congruent product. }\end{array}$ \\
\hline 5.3 & I: A*C & $\begin{array}{l}\text { Relational brand experience will be highest for an authentic celebrity } \\
\text { endorsement of a congruent product. }\end{array}$ \\
\hline
\end{tabular}

\section{Positive Celebrity Impression:}

\begin{tabular}{|c|l|l|}
\hline H & \multicolumn{1}{|c|}{ Effect } & \multicolumn{1}{c|}{ Hypothesis Statement } \\
\hline 6.1 & M: A & $\begin{array}{l}\text { Positive celebrity impression will be highest for authentic celebrity } \\
\text { endorsement. }\end{array}$ \\
\hline 6.2 & M: C & $\begin{array}{l}\text { Positive celebrity impression will be highest for celebrity endorsement of a } \\
\text { congruent product. }\end{array}$ \\
\hline 6.3 & I: A*C & $\begin{array}{l}\text { Positive celebrity impression will be highest for an authentic celebrity } \\
\text { endorsement of a congruent product. }\end{array}$ \\
\hline
\end{tabular}

\section{Celebrity Loyalty:}

\begin{tabular}{|c|l|l|}
\hline H & \multicolumn{1}{|c|}{ Effect } & \multicolumn{1}{c|}{ Hypothesis Statement } \\
\hline 7.1 & M: A & Celebrity loyalty will be highest for authentic celebrity endorsement. \\
\hline 7.2 & M: C & $\begin{array}{l}\text { Celebrity loyalty will be highest for celebrity endorsement of a congruent } \\
\text { product. }\end{array}$ \\
\hline 7.3 & I: A*C & $\begin{array}{l}\text { Celebrity loyalty will be highest for authentic celebrity endorsement of a } \\
\text { congruent product. }\end{array}$ \\
\hline
\end{tabular}

\section{Celebrity Positive Word of Mouth:}

\begin{tabular}{|c|l|l|}
\hline H & \multicolumn{1}{|c|}{ Effect } & \multicolumn{1}{c|}{ Hypothesis Statement } \\
\hline 8.1 & M: A & Positive word of mouth will be highest for authentic celebrity endorsement. \\
\hline 8.2 & M: C & $\begin{array}{l}\text { Positive word of mouth will be highest for celebrity endorsement of a } \\
\text { congruent product. }\end{array}$ \\
\hline 8.3 & I: A*C & $\begin{array}{l}\text { Positive word of mouth will be highest for authentic celebrity endorsement } \\
\text { of a congruent product. }\end{array}$ \\
\hline
\end{tabular}

\section{Celebrity Similarity:}

\begin{tabular}{|c|l|l|}
\hline H & \multicolumn{1}{|c|}{ Effect } & \multicolumn{1}{c|}{ Hypothesis Statement } \\
\hline 9.1 & M: A & Celebrity similarity will be highest for authentic celebrity endorsement. \\
\hline 9.2 & M: C & $\begin{array}{l}\text { Celebrity similarity will be highest for celebrity endorsement of a } \\
\text { congruent product. }\end{array}$ \\
\hline 9.3 & I: A*G & $\begin{array}{l}\text { Celebrity similarity will be highest for authentic celebrity endorsement of a } \\
\text { congruent product. }\end{array}$ \\
\hline
\end{tabular}




\section{Emotional Connection to Celebrity:}

\begin{tabular}{|c|l|l|}
\hline H & \multicolumn{1}{|c|}{ Effect } & \multicolumn{1}{c|}{ Hypothesis Statement } \\
\hline 10.1 & M: A & $\begin{array}{l}\text { Emotional connection to the celebrity will be highest for authentic celebrity } \\
\text { endorsement. }\end{array}$ \\
\hline 10.2 & M: C & $\begin{array}{l}\text { Emotional connection to the celebrity will be highest for celebrity } \\
\text { endorsement of a congruent product. }\end{array}$ \\
\hline 10.3 & I: A*C & $\begin{array}{l}\text { Emotional connection to the celebrity will be highest for authentic celebrity } \\
\text { endorsement of a congruent product }\end{array}$ \\
\hline
\end{tabular}

\section{Brand Loyalty:}

\begin{tabular}{|c|l|l|}
\hline H & \multicolumn{1}{|c|}{ Effect } & \multicolumn{1}{c|}{ Hypothesis Statement } \\
\hline 11.1 & M: A & Brand loyalty will be highest for authentic celebrity endorsement. \\
\hline 11.2 & M: C & $\begin{array}{l}\text { Brand loyalty will be highest for celebrity endorsement of a congruent } \\
\text { product. }\end{array}$ \\
\hline 11.3 & I: A*C & $\begin{array}{l}\text { Brand loyalty will be highest for an authentic celebrity endorsement of a } \\
\text { congruent product. }\end{array}$ \\
\hline
\end{tabular}

\section{Willingness to Buy (Purchase Intentions):}

\begin{tabular}{|c|l|l|}
\hline H & \multicolumn{1}{|c|}{ Effect } & \multicolumn{1}{c|}{ Hypothesis Statement } \\
\hline 12.1 & M: A & Purchase intentions will be highest for authentic celebrity endorsement. \\
\hline 12.2 & M: C & $\begin{array}{l}\text { Purchase intentions will be highest for celebrity endorsement of a } \\
\text { congruent product. }\end{array}$ \\
\hline 12.3 & I: A*C & $\begin{array}{l}\text { Purchase intentions will be highest for an authentic celebrity endorsement } \\
\text { of a congruent product. }\end{array}$ \\
\hline
\end{tabular}

\section{Willingness to Purchase at a Premium:}

\begin{tabular}{|c|l|l|}
\hline H & \multicolumn{1}{|c|}{ Effect } & \multicolumn{1}{c|}{ Hypothesis Statement } \\
\hline 13.1 & M: A & $\begin{array}{l}\text { Willingness to purchase at a premium will be highest for authentic } \\
\text { celebrity endorsement. }\end{array}$ \\
\hline 13.2 & M: C & $\begin{array}{l}\text { Willingness to purchase at a premium will be highest for celebrity } \\
\text { endorsement of a congruent product. }\end{array}$ \\
\hline 13.3 & I: A*C & $\begin{array}{l}\text { Willingness to purchase at a premium will be highest for an authentic } \\
\text { celebrity endorsement of a congruent product. }\end{array}$ \\
\hline
\end{tabular}

\section{Overall Brand Satisfaction:}

\begin{tabular}{|c|l|l|}
\hline H & \multicolumn{1}{|c|}{ Effect } & \multicolumn{1}{c|}{ Hypothesis Statement } \\
\hline 14.1 & M: A & Brand satisfaction will be highest for authentic celebrity endorsement. \\
\hline 14.2 & M: C & $\begin{array}{l}\text { Brand satisfaction will be highest for celebrity endorsement of a congruent } \\
\text { product. }\end{array}$ \\
\hline 14.3 & I: A*C & $\begin{array}{l}\text { Brand satisfaction will be highest for an authentic celebrity endorsement of } \\
\text { a congruent product. }\end{array}$ \\
\hline
\end{tabular}




\section{Overall Positive Brand Impression:}

\begin{tabular}{|c|l|l|}
\hline H & Effect & \multicolumn{1}{c|}{ Hypothesis Statement } \\
\hline 15.1 & M: A & $\begin{array}{l}\text { Positive brand impression will be highest for authentic celebrity } \\
\text { endorsement. }\end{array}$ \\
\hline 15.2 & M: C & $\begin{array}{l}\text { Positive brand impression will be highest for celebrity endorsement of a } \\
\text { congruent product. }\end{array}$ \\
\hline 15.3 & I: A*C & $\begin{array}{l}\text { Positive brand impression will be highest for authentic celebrity } \\
\text { endorsement of a congruent product. }\end{array}$ \\
\hline
\end{tabular}

\section{Methodology}

Experiment Design

In order to test my hypotheses, I established a 2x2x2 experimental design manipulating authenticity, product congruence and gender. The design contains two levels of authenticity (authentic and not authentic), two levels of congruence (congruent and not congruent) and two gender identities of the celebrity (male and female). Gender was included as a control variable in order to control for any unintended influence. It is not a variable expected to have any theory-based influence. Therefore, I expect that there will be no difference in scores whether respondents are exposed to a female endorser versus a male endorser and it is not included in my hypotheses tables. The dependent variables measured include the five aspects of brand experience (sensory, affective, cognitive, behavioral and relational), celebrity evaluation (emotional connection, loyalty, similarity, positive word-of-mouth and overall impressions) and brand evaluation (loyalty, willingness to buy, purchase at a premium, overall impressions and overall satisfaction). Eight distinct scenarios were created with different combinations of authenticity levels (A or NA), product congruency levels (C or NC), and gender (Male or Female).

\begin{tabular}{|l|l|l|}
\hline Male Celebrity & Authentic & Not Authentic \\
\hline Congruent & A - C (Scenario 1) & NA - C (Scenario 3) \\
\hline Not Congruent & A - NC (Scenario 2) & NA - NC (Scenario 4) \\
\hline
\end{tabular}

\begin{tabular}{|l|l|l|}
\hline Female Celebrity & Authentic & Not Authentic \\
\hline Congruent & A $-\mathrm{C}($ Scenario 5) & NA - C (Scenario 7) \\
\hline Not Congruent & A - NC (Scenario 6) & NA - NC (Scenario 8) \\
\hline
\end{tabular}

In order to minimize extraneous factors resulting from personal connections or differing levels of familiarity with real-life celebrities, a vignette approach was utilized. Respondents were exposed to one of eight scenarios. Each of the scenarios contained a photo of a generic, white male or female named John or Jane Smith, depending on which scenario the respondent was randomly assigned to, smiling and wearing a chef's outfit. Below the photograph, there was a paragraph describing the chef's celebrity status and then a paragraph describing the celebrity as authentic or not authentic. Based on previously validated measures, celebrity authenticity can be measured by rarity and stability (Moulard et al. 2015). The sub-dimensions behind rarity include talent, discretion and originality and the sub-dimensions behind stability are consistency, candidness and morality (Moulard et al. 2015). I utilized these sub- 
dimensions in the second paragraph to depict the authenticity or lack of authenticity of the celebrity vignette pictured above. For the full scenario, please refer to the Appendix. Next, respondents were exposed to a photo of a can of salsa (congruent product) or a tube of toothpaste (not congruent product), depending on the scenario they were randomly assigned, that contained a photo of the chef and copy reading "Brand X" and "Endorsed by: Chef (Jane or John) Smith." These products were selected due to their similarity of involvement and pricing in order to minimize extraneous factors. For the full scenario, please refer to the Appendix. Respondents were then asked to evaluate the celebrity and the brand based on the dependent variables related to celebrity evaluation, brand evaluation and brand experience on a five-point scale ranging from "Strongly Disagree" to "Strongly Agree." For the full list of questions, please refer to the Appendix.

Prior to releasing the survey, a pre-test was administered to 48 respondents. This pre-test was a manipulation check to determine whether respondents recognized the differences between authentic and not authentic as well as congruent and not congruent. It was also used to determine that there was no significant difference between male and female conditions. Respondents understood the difference between the authentic and not authentic scenarios ( $t=14.89$, $d f=84, p<.05)$. Respondents also understood the difference between congruent and not congruent products $(t=5.45$, $\mathrm{df}=84, \mathrm{p}<.05)$. There was no significant difference between the male and female conditions. After this understanding was established, I proceeded to conduct the study. Manipulation checks were integrated into the full study as to ensure respondent understanding continues.

The survey contained seven sections: consent, scenarios, manipulation check questions, celebrity evaluation questions, brand evaluation questions, brand experience questions and demographics. Respondents were first exposed to the consent section that explained the survey. They were required to agree to the consent form before proceeding. Next, they were exposed to one of the eight previously described scenarios. These scenarios were randomly assigned to respondents by Qualtrics.

\begin{tabular}{|l|l|l|}
\hline Male Celebrity & Authentic & Not Authentic \\
\hline Congruent & A - C (Scenario 1) & NA - C (Scenario 3) \\
\hline Not Congruent & A - NC (Scenario 2) & NA - NC (Scenario 4) \\
\hline
\end{tabular}

\begin{tabular}{|l|l|l|}
\hline Female Celebrity & Authentic & Not Authentic \\
\hline Congruent & A - C (Scenario 5) & NA - C (Scenario 7) \\
\hline Not Congruent & A - NC (Scenario 6) & NA - NC (Scenario 8) \\
\hline
\end{tabular}

Next, respondents were asked to rate a set of statements that measured respondents' evaluation of the celebrity's level of authenticity on a five-point scale. The purpose of this set of statements was to validate that respondents understood the difference between the authentic and not authentic conditions. Next, respondents were asked to evaluate statements about the celebrity related to loyalty, word of mouth, emotional connection and overall impressions on a five-point scale. After this, respondents were asked to rate statements related to the relationship between "Brand X" and "Chef Smith" on a five-point scale. The purpose of this set of statements was to validate that respondents understood the difference between the congruent and not congruent products. Next, respondents were asked to rate statements related to brand evaluation including loyalty, willingness to purchase product, willingness to purchase product at a premium, overall satisfaction and overall impressions on a five-point scale. Next, respondents were asked to rate statements related to the five components of brand experience (sensory, affective, cognitive, behavioral and relational). Lastly, basic 
demographic and psychographic information was captured including gender, race, classification at TCU, household income range and social media use. Additionally, questions regarding evaluations of personal cooking skills, interest in any real-life chef celebrities and interest in television shows related to cooking were asked. The data collected from this survey is all with the intention to better understand how authenticity of celebrity endorsers and product congruence affect brand experience.

The survey was administered for seven days from February 23rd to March 2nd via Qualtrics software. There were 326 respondents total, with 222 completed responses viable for analysis. All scenarios received at least 24 responses to ensure that there is enough power in analysis models to detect differences between experimental conditions.

\title{
Analysis Measures
}

An analysis of variance, otherwise known as ANOVA, was used to analyze the data collected in this study. The ANOVA test was ran using SPSS statistics software. This method is a statistical model that analyzes if there are statistically significant differences among groups of means and their assigned experimental conditions. I ran an ANOVA test to measure the impact of my independent variables (authenticity, congruence and gender) on each dependent variable. In some cases, multiple statements were used to measure a particular dependent variable. To ensure reliability that these statements do, in fact, measure the same variable, I found the Cronbach's alpha using SPSS statistics software before running the ANOVA test. The Cronbach's alpha is a measure of reliability. For all cases in which the dependent variable was measured using multiple statements, the Cronbach's alpha was greater than .7, indicating sufficient reliability.

\section{Results and Interpretation Brand Experience Sensory Experience}

\author{
Results
}

When evaluating sensory brand experience, the overall model fit is significant $\left(F_{7,222}=3.580, p<.05\right)$. The hypothesis identification number, manipulation effect, ANOVA results and whether or not the hypothesis statement is supported is provided in the table below.

\begin{tabular}{|c|l|l|l|}
\hline H & \multicolumn{1}{|c|}{ Effect } & \multicolumn{1}{|c|}{$\begin{array}{c}\text { ANOVA } \\
\text { Results }\end{array}$} & \multicolumn{1}{c|}{ Findings } \\
\hline 1.1 & $\mathrm{M}: \mathrm{A}$ & $\begin{array}{l}\mathrm{F}_{1,222}=8.240 \\
\mathrm{p}<.05\end{array}$ & $\begin{array}{l}\text { Hypothesis supported: } \\
\text { Celebrity endorsement authenticity has a statistically } \\
\text { significant impact on sensory brand experience }\end{array}$ \\
\hline 1.2 & $\mathrm{M}: \mathrm{C}$ & $\begin{array}{l}\mathrm{F}_{1,222}=9.990 \\
\mathrm{p}<.05\end{array}$ & $\begin{array}{l}\text { Hypothesis supported: } \\
\text { Product congruency has a statistically significant impact on } \\
\text { sensory brand experience }\end{array}$ \\
\hline 1.3 & $\mathrm{I}: \mathrm{A}^{* \mathrm{C}}$ & $\begin{array}{l}\mathrm{F}_{1,222}=1.492 \\
\mathrm{p}>.05\end{array}$ & $\begin{array}{l}\text { Hypothesis not supported: } \\
\text { Together, celebrity endorsement authenticity and product } \\
\text { congruency have no statistically significant impact on } \\
\text { sensory brand experience. }\end{array}$ \\
\hline $\mathrm{I}: \mathrm{A} * \mathrm{C}^{*} \mathrm{G}$ & $\begin{array}{l}\mathrm{F}_{1,222}=9.990 \\
\mathrm{p}<.10\end{array}$ & $\begin{array}{l}\text { The combination of celebrity endorsement authenticity, } \\
\text { product congruency and gender has a statistically } \\
\text { significant impact on sensory brand experience at a } \\
\text { significance level of .05. Sensory experience was higher } \\
\text { for an authentic female than a non-authentic female. For } \\
\text { male endorsement, there was no difference. This effect } \\
\text { only held true when endorsing a congruent } \text { product. [See } \\
\text { Sensory (Congruent) and Sensory (Not Congruent) below] }\end{array}$ \\
\hline
\end{tabular}



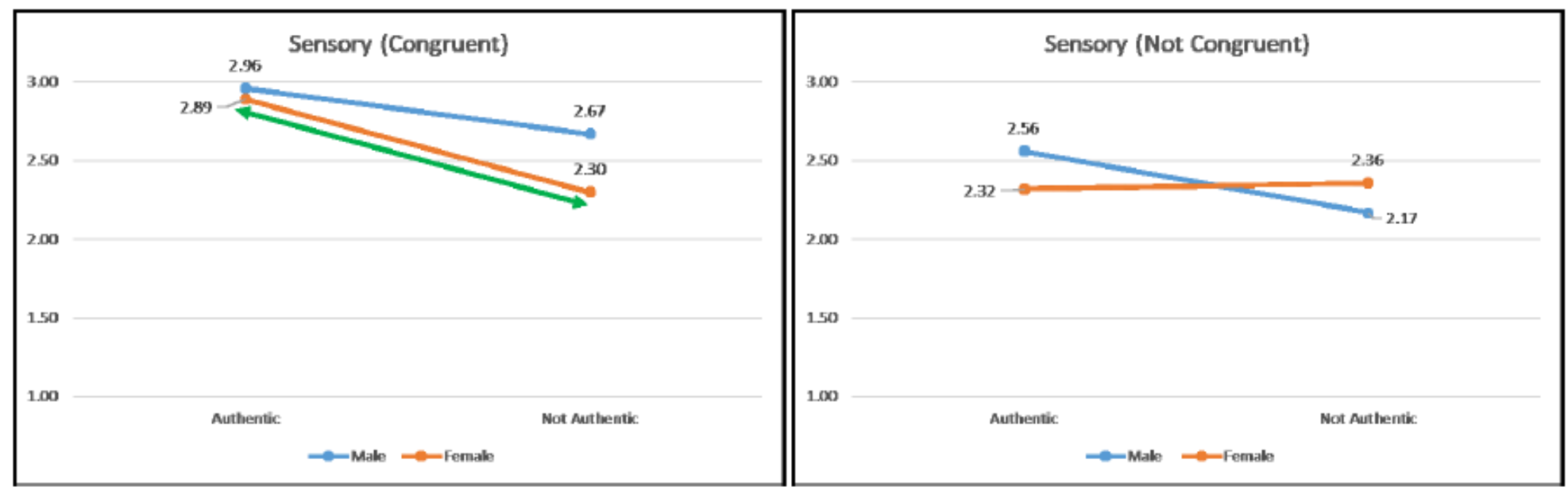

\section{Interpretation}

When looking to enhance sensory brand experience, or stimuli contributing to a consumer's five senses_touch, taste, smell, sight and hearing (Brakus, 2009)_authenticity and congruence make an impact. If a brand manager's objective is to enhance sensory brand experience, the endorsement would be more effective with an authentic endorser and an endorser that is congruent with the brand's product or product category. Although there is not strong enough evidence to suggest that the combination of an authentic celebrity endorsing a congruent product, in this case salsa, has a significantly different effect on sensory brand experience from other combinations, my hypothesis $\left(A^{\star} C\right)$ remains directionally supported. Additionally, although not originally hypothesized $\left(A^{*} C{ }^{\star} G\right)$, gender plays a role in sensory experience. Results showed that respondents exposed to Jane Smith (F) endorsing salsa (C) had a significantly higher sensory brand experience if she was described as authentic (A) versus not authentic (NA). Therefore, if a brand manager selects a female endorser that is also congruent with the brand product or product category, sensory experience would be greater if the endorser was also authentic.

\section{Affective Experience

\author{
Results
}

When evaluating affective brand experience, the overall model fit is significant $\left(F_{7,222}=2.583, p<.05\right)$. The hypothesis identification number, manipulation effect, ANOVA results and whether or not the hypothesis statement is supported is provided in the table below.

\begin{tabular}{|l|l|l|l|}
\hline H & Effect & \multicolumn{1}{|c|}{$\begin{array}{c}\text { ANOVA } \\
\text { Results }\end{array}$} & \multicolumn{1}{c|}{ Findings } \\
\hline 2.1 & $\mathrm{M}: \mathrm{A}$ & $\begin{array}{l}\mathrm{F}_{1,222}=7.744 \\
\mathrm{p}<.05\end{array}$ & $\begin{array}{l}\text { Hypothesis supported: } \\
\text { Celebrity endorsement authenticity has a statistically } \\
\text { significant impact on sensory brand experience }\end{array}$ \\
\hline 2.2 & $\mathrm{M}: \mathrm{C}$ & $\begin{array}{l}\mathrm{F}_{1,222}=4.610 \\
\mathrm{p}<.05\end{array}$ & $\begin{array}{l}\text { Hypothesis supported: } \\
\text { Product congruency has a statistically significant impact on } \\
\text { sensory brand experience }\end{array}$ \\
\hline 2.3 & $\mathrm{I}: \mathrm{A}^{*} \mathrm{C}$ & $\begin{array}{l}\mathrm{F}_{1,222}=.140 \\
\mathrm{p}>.05\end{array}$ & $\begin{array}{l}\text { Hypothesis not supported: } \\
\text { Together, celebrity endorsement authenticity and product } \\
\text { congruency have no statistically significant impact on } \\
\text { affective brand experience. }\end{array}$ \\
\hline
\end{tabular}




\section{Interpretation}

When looking to enhance affective brand experience, or the brand's ability to encourage consumers to have an emotional connection to the brand (Brakus, 2009), authenticity and congruence make an impact. This means that if brand managers were looking to enhance affective brand experience, it would be better to select a celebrity that is authentic and a celebrity that is congruent with the product or product category. Although there is not strong enough evidence to suggest the combination of an authentic celebrity endorsing a congruent product, in this case salsa, has a significantly different effect on affective brand experience from other combinations, my hypothesis $(A * C)$ remains directionally supported.

\section{Cognitive Brand Experience}

Results

When evaluating cognitive brand experience, the overall model fit is not significant $\left(F_{7,222}=.961, p>.05\right)$. Therefore, I conclude that celebrity endorsement authenticity and product congruency have no effect on cognitive brand experience.

\section{Interpretation}

Authenticity and congruence do not significantly enhance cognitive brand experience, the brand's ability to challenge consumers to think intellectually (Brakus, 2009). If brand managers are looking to enhance cognitive brand experience through celebrity endorsement, authenticity and congruence are not the best predictors. Brand managers may want to look at other components of the endorsement or overall brand strategy to optimize cognitive brand experience.

\section{Behavioral Brand Experience}

\section{Results}

When evaluating behavioral brand experience, the overall model fit is marginally significant at a p-value of .10 $\left(F_{7,222}=1.782, p<.10\right)$, therefore I conclude that celebrity endorsement and product congruency has partial effect on behavioral brand experience. The hypothesis identification number, manipulation effect, ANOVA results and whether or not the hypothesis statement is supported is provided in the table below.

\begin{tabular}{|c|l|l|l|}
\hline H & Effect & \multicolumn{1}{|c|}{$\begin{array}{c}\text { ANOVA } \\
\text { Results }\end{array}$} & \multicolumn{1}{c|}{ Findings } \\
\hline 4.1 & $\mathrm{M}: \mathrm{A}$ & $\begin{array}{l}\mathrm{F}_{1,222}=.783 \\
\mathrm{p}>.05\end{array}$ & $\begin{array}{l}\text { Hypothesis not supported: } \\
\text { Celebrity endorsement authenticity has no statistically } \\
\text { significant impact on behavioral brand experience }\end{array}$ \\
\hline 4.2 & $\mathrm{M}: \mathrm{C}$ & $\begin{array}{l}\mathrm{F}_{1,222}=7.962 \\
\mathrm{p}<.05\end{array}$ & $\begin{array}{l}\text { Hypothesis supported: } \\
\text { Product congruency has a statistically significant impact on } \\
\text { behavioral brand experience }\end{array}$ \\
\hline 4.3 & $\mathrm{I}: \mathrm{A}^{*} \mathrm{C}$ & $\begin{array}{l}\mathrm{F}_{1,222}=.002 \\
\mathrm{p}>.05\end{array}$ & $\begin{array}{l}\text { Hypothesis not supported: } \\
\text { Together, celebrity endorsement authenticity and product } \\
\text { congruency have no statistically significant impact on } \\
\text { affective brand experience. }\end{array}$ \\
\hline
\end{tabular}




\section{Interpretation}

When looking to enhance behavioral brand experience, or the brand's ability to evoke behavior when utilizing a product (Brakus, 2009), product congruence makes an impact. This means that if brand managers were looking to enhance behavioral brand experience, it would be better to select a celebrity that is congruent with their product or product category than not congruent. There is not strong enough evidence to suggest that authenticity plays a role in enhancing behavioral brand experience. There is also not enough evidence to suggest the combination of an authentic celebrity endorsing a congruent product, in this case salsa, has a statistically significantly different effect on behavioral brand experience from other combinations.

\section{Relational Brand Experience}

Results

When evaluating relational brand experience, the overall model fit is significant $\left(F_{7,222}=2.786, p<.05\right)$. The hypothesis identification number, manipulation effect, ANOVA results and whether or not the hypothesis statement is supported is provided in the table below.

\begin{tabular}{|c|l|l|l|}
\hline H & Effect & \multicolumn{1}{|c|}{$\begin{array}{c}\text { ANOVA } \\
\text { Results }\end{array}$} & \multicolumn{1}{c|}{ Findings } \\
\hline 5.1 & $\mathrm{M}: \mathrm{A}$ & $\begin{array}{l}\mathrm{F}_{1,222}=6.117 \\
\mathrm{p}<.05\end{array}$ & $\begin{array}{l}\text { Hypothesis supported: } \\
\text { Celebrity endorsement authenticity has a statistically } \\
\text { significant impact on sensory brand experience }\end{array}$ \\
\hline 5.2 & $\mathrm{M}: \mathrm{C}$ & $\begin{array}{l}\mathrm{F}_{1,222}=7.325 \\
\mathrm{p}<.05\end{array}$ & $\begin{array}{l}\text { Hypothesis supported: } \\
\text { Product congruency has a statistically significant impact on } \\
\text { sensory brand experience }\end{array}$ \\
\hline 5.3 & $\mathrm{I}: \mathrm{A}^{*} \mathrm{C}$ & $\begin{array}{l}\mathrm{F}_{1,222}=.528 \\
\mathrm{p}>.05\end{array}$ & $\begin{array}{l}\text { Hypothesis not supported: } \\
\text { Together, celebrity endorsement authenticity and product } \\
\text { congruency have no statistically significant impact on } \\
\text { affective brand experience. }\end{array}$ \\
\hline
\end{tabular}

\section{Interpretation}

When looking to enhance relational brand experience, or the brand's ability to engage with a consumer relationally, authenticity and congruence make an impact. This means that if brand managers were looking to enhance relational brand experience, it would be better to select a celebrity that is authentic and a celebrity that is congruent with the product or product category. Although there is not strong enough evidence to suggest the combination of an authentic celebrity endorsing a congruent product, in this case salsa, has a significantly different effect on relational brand experience from other combinations, my hypothesis $\left(A^{\star} C\right)$ remains directionally supported.

\section{Celebrity Evalutation \\ Positive Celebrity Impression \\ Results}

When evaluating positive celebrity impressions, the overall model fit is significant $\left(F_{7,222}=32.645, p<.05\right)$. The hypothesis identification number, manipulation effect, ANOVA results and whether or not the hypothesis statement is supported is provided in the table below.

(see next page for table) 


\begin{tabular}{|l|l|l|l|}
\hline H & \multicolumn{1}{|c|}{ Effect } & \multicolumn{1}{|c|}{$\begin{array}{c}\text { ANOVA } \\
\text { Results }\end{array}$} & \multicolumn{1}{c|}{ Findings } \\
\hline 6.1 & M: A & $\begin{array}{l}\mathrm{F}_{1,222}= \\
213.11 \\
\mathrm{p}<.05\end{array}$ & $\begin{array}{l}\text { Hypothesis supported: } \\
\text { Celebrity endorsement authenticity has a statistically } \\
\text { significant impact on positive celebrity impressions. }\end{array}$ \\
\hline 6.2 & M: C & $\begin{array}{l}\mathrm{F}_{1,222}=6.012 \\
\mathrm{p}<.05\end{array}$ & $\begin{array}{l}\text { Hypothesis supported: } \\
\text { Product congruency has a statistically significant impact on } \\
\text { positive celebrity impressions. }\end{array}$ \\
\hline 6.3 & $\mathrm{I}: \mathrm{A}^{* \mathrm{C}}$ & $\begin{array}{l}\mathrm{F}_{1,222}=.723 \\
\mathrm{p}>.05\end{array}$ & $\begin{array}{l}\text { Hypothesis not supported: } \\
\text { Together, celebrity endorsement authenticity and product } \\
\text { congruency have no statistically significant impact on } \\
\text { positive celebrity impressions. }\end{array}$ \\
\hline I: $\mathrm{A}^{*} \mathrm{C}^{*} \mathrm{G}$ & $\begin{array}{l}\mathrm{F}_{1,222}=3.510 \\
\mathrm{p}<.10\end{array}$ & $\begin{array}{l}\text { The combination of celebrity endorsement authenticity, } \\
\text { product congruency and gender has a statistically significant } \\
\text { impact on positive celebrity impressions at a .10 level of } \\
\text { significance. Celebrity impressions were significantly higher } \\
\text { for a congruent female endorser than a non-congruent } \\
\text { female endorser. For male endorsement, there was no } \\
\text { difference. This effect only held true when the endorser was } \\
\text { deemed authentic. [See Celebrity Impression (Authentic) } \\
\text { and Celebrity Impression (Not Authentic)] }\end{array}$ \\
\hline
\end{tabular}
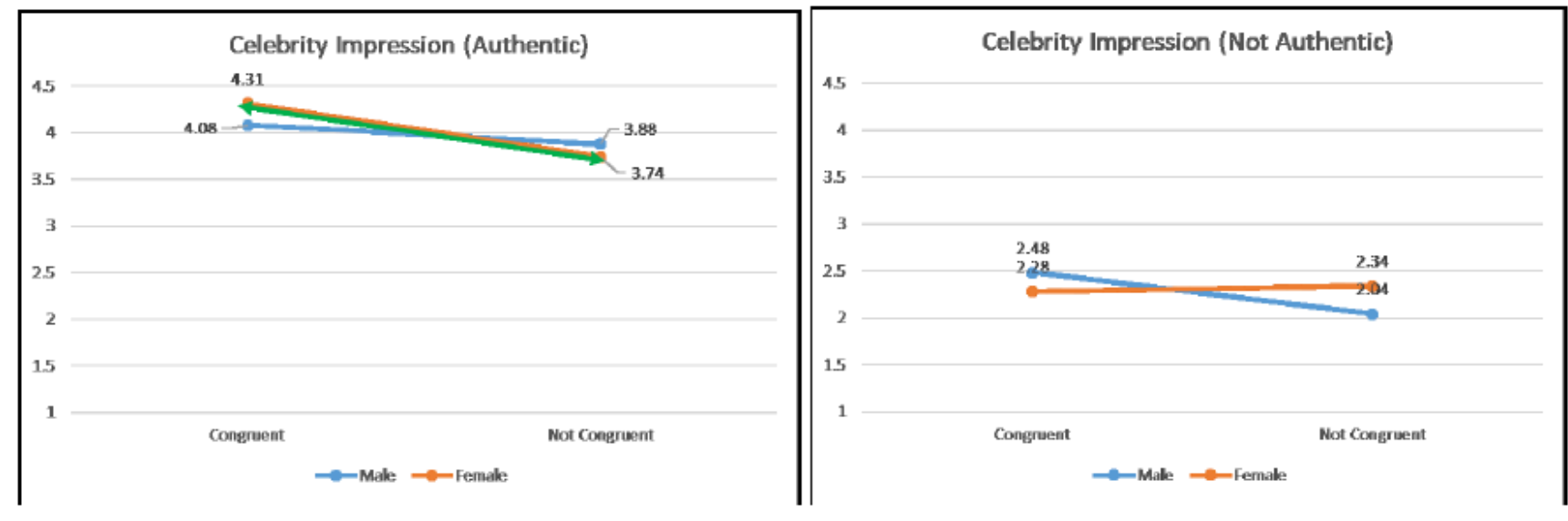

Interpretation

When looking at whether respondents had positive impressions of Chef Jane or John Smith, authenticity and congruence make an impact. This means that if brand managers were looking to enhance or evaluate the impressions people have of a particular endorser, respondents have a better impression of a celebrity that is authentic and a celebrity that is congruent with the product or product category. Although there is not strong enough evidence to suggest the combination of an authentic celebrity endorsing a congruent product, in this case salsa, has a significantly different effect on positive celebrity impressions from other combinations, my hypothesis $\left(A^{\star} C\right)$ remains directionally supported. Additionally, although not originally hypothesized $\left(A^{\star} C^{\star} G\right)$, gender plays a role in respondents' impressions of given celebrity endorsers. Results showed that respondents exposed to Jane Smith (F) who was described as authentic (A) had significantly better impressions if she was congruent (C) versus not congruent (NC) with the brand's product or product category. Therefore, if a brand manager selects a female endorser that is also authentic, people will have better impressions of the endorser if she is also congruent with the brand's product or product category. 


\section{Celebrity Loyalty}

Results

When evaluating celebrity loyalty, the overall model fit is significant $\left(F_{7,222}=11.776, p<.05\right)$. The hypothesis identification number, manipulation effect, ANOVA results and whether or not the hypothesis statement is supported is provided in the table below.

\begin{tabular}{|l|l|l|l|}
\hline H & \multicolumn{1}{|c|}{ Effect } & \multicolumn{1}{|c|}{$\begin{array}{c}\text { ANOVA } \\
\text { Results }\end{array}$} & \multicolumn{1}{c|}{ Findings } \\
\hline 7.1 & M: A & $\begin{array}{l}\mathrm{F}_{1,222}= \\
68.556 \\
\mathrm{p}<.05\end{array}$ & $\begin{array}{l}\text { Hypothesis supported: } \\
\text { Celebrity endorsement authenticity has a statistically } \\
\text { significant impact on celebrity loyalty. }\end{array}$ \\
\hline 7.2 & $\mathrm{M}: \mathrm{C}$ & $\begin{array}{l}\mathrm{F}_{1,222}=1.993 \\
\mathrm{p}>.05\end{array}$ & $\begin{array}{l}\text { Hypothesis not supported: } \\
\text { Product congruency has no statistically significant impact on } \\
\text { celebrity loyalty. }\end{array}$ \\
\hline 7.3 & $\mathrm{I}: \mathrm{A}^{*} \mathrm{C}$ & $\begin{array}{l}\mathrm{F}_{1,222}=1.497 \\
\mathrm{p}>.05\end{array}$ & $\begin{array}{l}\text { Hypothesis not supported: } \\
\text { Together, celebrity endorsement authenticity and product } \\
\text { congruency have no statistically significant impact on } \\
\text { celebrity loyalty. }\end{array}$ \\
\hline $\mathrm{I}: \mathrm{A}^{*} \mathrm{C}^{*} \mathrm{G}$ & $\begin{array}{l}\mathrm{F}_{1,222}=5.026 \\
\mathrm{p}<.05\end{array}$ & $\begin{array}{l}\text { The combination of celebrity endorsement authenticity, } \\
\text { product congruency and gender has a statistically significant } \\
\text { impact on celebrity loyalty at a .05 level of significance. } \\
\text { Celebrity loyalty was significantly higher for a congruent } \\
\text { female endorser than a non-congruent female endorser. For } \\
\text { male endorsement, there was no difference. This effect only } \\
\text { held true when the endorser was deemed authentic. [See } \\
\text { Celebrity Impression (Authentic) and Celebrity Impression } \\
\text { (Not Authentic)] }\end{array}$ \\
\hline
\end{tabular}
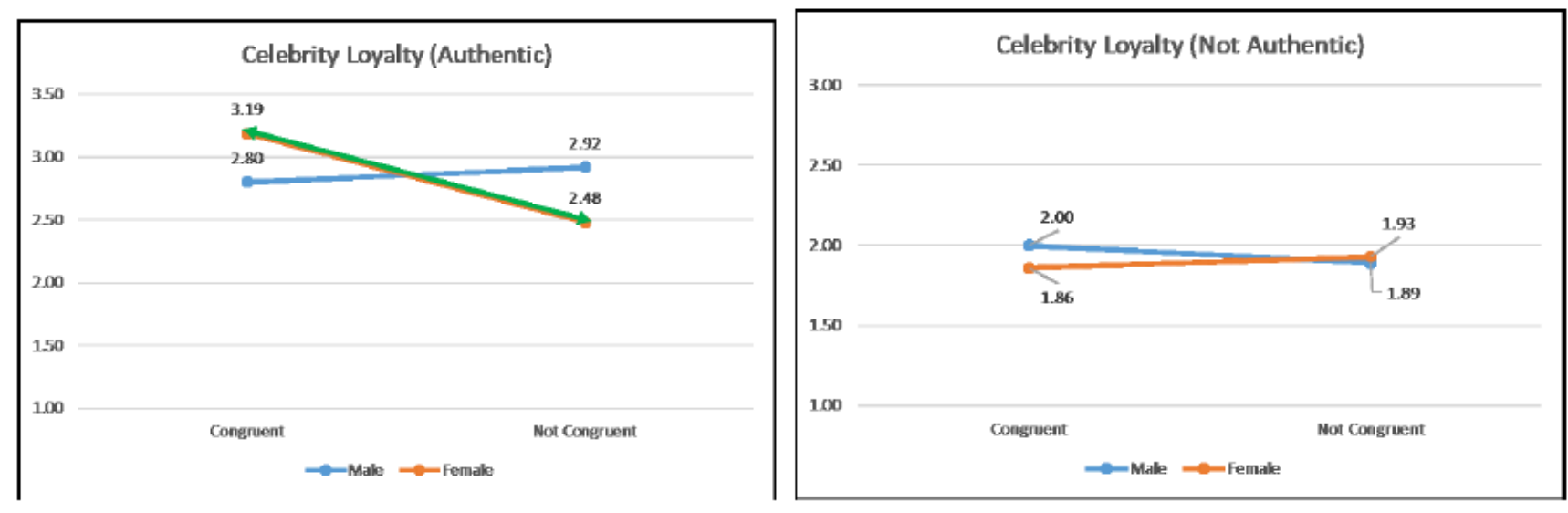

\section{Interpretation}

When looking at whether respondents felt loyal towards Chef Jane or John Smith, authenticity and congruence made an impact. This means that if brand managers were looking to enhance or evaluate the loyalty people feel towards a given endorser, people have stronger loyalty towards a celebrity that is authentic and a celebrity that is congruent with the product or product category. Although there is not strong enough evidence to suggest the combination of an authentic celebrity endorsing a congruent product, in this case salsa, has a significantly different effect on loyalty towards the endorser than other combinations, my hypothesis $\left(A^{\star} C\right)$ remains directionally supported. Additionally, although not originally hypothesized $\left(A^{\star} C^{\star} G\right)$, gender plays a role in respondents' loyalty towards a given celebrity endorser. Results showed that respondents exposed to Jane Smith (F) who was described as authentic (A) had significantly more loyalty if she was congruent (C) versus not congruent (NC) with the brand's product or product category. Therefore, if a brand manager selects a female endorser that is also authentic, people will feel more loyalty towards the endorser if she is also congruent with the brand's product or product category. 


\section{Celebrity Word of Mouth}

Results

When evaluating celebrity word of mouth, the overall model fit is significant $\left(F_{7,222}=16.440, p<.05\right)$. The hypothesis identification number, manipulation effect, ANOVA results and whether or not the hypothesis statement is supported is provided in the table below.

\begin{tabular}{|l|l|l|l|}
\hline H & \multicolumn{1}{|c|}{ Effect } & \multicolumn{1}{|c|}{$\begin{array}{c}\text { ANOVA } \\
\text { Results }\end{array}$} & \multicolumn{1}{c|}{ Findings } \\
\hline 8.1 & M: $\mathrm{A}$ & $\begin{array}{l}\mathrm{F}_{1,222}=88.841 \\
\mathrm{p}<.05\end{array}$ & $\begin{array}{l}\text { Hypothesis supported: } \\
\text { Celebrity endorsement authenticity has a statistically } \\
\text { significant impact on celebrity word of mouth. }\end{array}$ \\
\hline 8.2 & $\mathrm{M}: \mathrm{C}$ & $\begin{array}{l}\mathrm{F}_{1,222}=4.777 \\
\mathrm{p}<.05\end{array}$ & $\begin{array}{l}\text { Hypothesis supported: } \\
\text { Product congruency has a statistically significant impact on } \\
\text { celebrity word of mouth. }\end{array}$ \\
\hline 8.3 & $\mathrm{I}: \mathrm{A}^{*} \mathrm{C}$ & $\begin{array}{l}\mathrm{F}_{1,222}=.618 \\
\mathrm{p}>.05\end{array}$ & $\begin{array}{l}\text { Hypothesis not supported: } \\
\text { Together, celebrity endorsement authenticity and product } \\
\text { congruency have no statistically significant impact on } \\
\text { celebrity word of mouth. }\end{array}$ \\
\hline & I:A*C* $\mathrm{G}$ & $\begin{array}{l}\mathrm{F}_{1,222}=13.918 \\
\mathrm{p}<.05\end{array}$ & $\begin{array}{l}\text { The combination of celebrity endorsement authenticity, } \\
\text { product congruency and gender has a statistically significant }\end{array}$ \\
\hline
\end{tabular}

\begin{tabular}{|l|l|l|}
\hline $\mid$ & $\begin{array}{l}\text { impact on celebrity word of mouth at a .05 significance } \\
\text { level. When a congruent product was endorsed, the female } \\
\text { endorser had significantly better word of mouth than the } \\
\text { male endorser. When a not congruent product was endorsed, } \\
\text { the male endorser had significantly better word of mouth. } \\
\text { Additionally, a female endorsing a congruent product had } \\
\text { significantly better word of mouth than a female endorsing a } \\
\text { non-congruent product. This was not the case for male } \\
\text { endorsement. These effects only held true when the endorser } \\
\text { was deemed as authentic. [See Positive Word of Mouth } \\
\text { (Authentic) and Positive Word of Mouth (Not Authentic)] }\end{array}$ \\
\hline
\end{tabular}

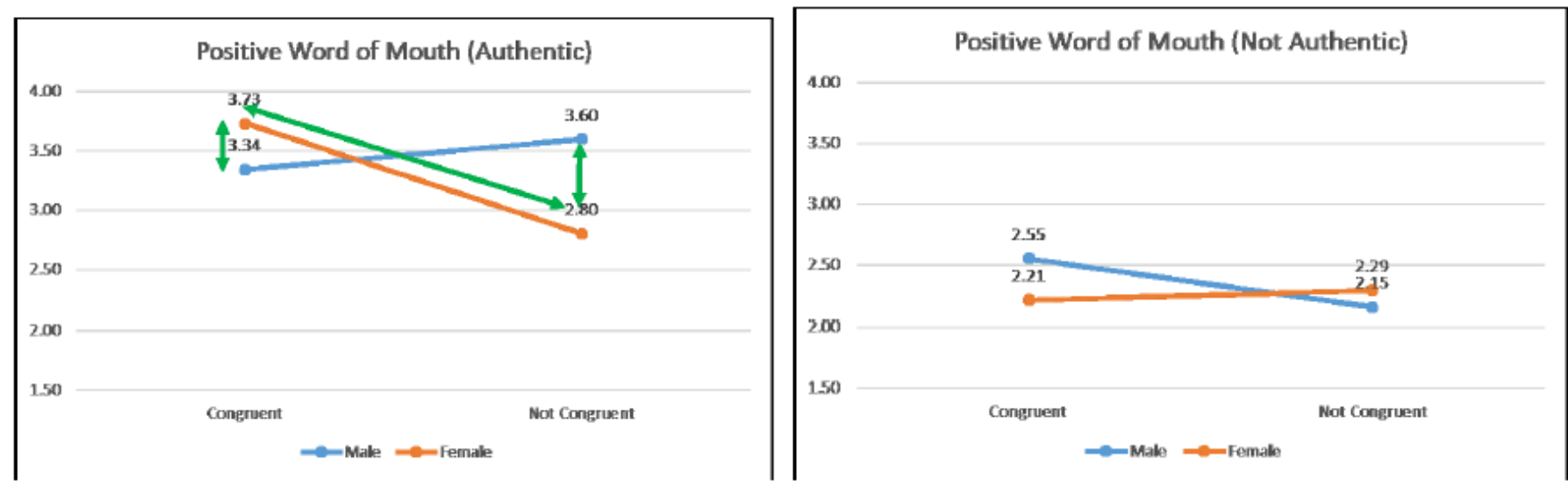

Interpretation

When looking at whether respondents had positive word of mouth or were likely to recommend Chef Jane and John Smith to others, authenticity and congruence made an impact. This means that if brand managers were looking to enhance or evaluate people's word of mouth towards a given endorser, people are more likely to recommend a celebrity that is authentic and a celebrity that is congruent with the product or product category. Although there is not strong enough evidence to suggest the combination of an authentic celebrity endorsing a congruent product, in this case salsa, has a significantly different effect on positive word of mouth than other combinations, my hypothesis 
$\left(A^{\star} C\right)$ remains directionally supported. Additionally, although not originally hypothesized $\left(A^{\star} C * G\right)$, gender plays a role in respondents' willingness to recommend a given celebrity endorser. Results showed that respondents would have more positive word of mouth towards Jane Smith (F) if she was described as authentic $(A)$ and if she was congruent $(\mathrm{C})$ versus not congruent $(\mathrm{NC})$ with the brand's product or product category. Additionally, respondents were more likely to recommend Jane Smith $(F)$ if salsa was endorsed but are more likely to recommend John Smith if toothpaste was endorsed (note: this effect only held true when deemed authentic). Therefore, if a brand manager selects a female endorser that is also authentic, people will be more likely to recommend her than a male endorser if she is endorsing a product congruent with the brand's product or product category. If a brand selects an authentic male endorser, people will be more likely to recommend him than a female endorser if he is endorsing a product not congruent with the brand's product or product category.

\section{Celebrity Similarity}

Results

When evaluating celebrity similarity, the overall model fit is significant $\left(F_{7,222}=18.786, p<.05\right)$. The hypothesis identification number, manipulation effect, ANOVA results and whether or not the hypothesis statement is supported is provided in the table below.

\begin{tabular}{|c|l|l|l|}
\hline H & Effect & \multicolumn{1}{|c|}{$\begin{array}{c}\text { ANOVA } \\
\text { Results }\end{array}$} & \multicolumn{1}{c|}{ Findings } \\
\hline 9.1 & M: A & $\begin{array}{l}\mathrm{F}_{1,222}= \\
120.81 \\
\mathrm{p}<.05\end{array}$ & $\begin{array}{l}\text { Hypothesis supported: } \\
\text { Celebrity endorsement authenticity has a statistically } \\
\text { significant impact on celebrity similarity. }\end{array}$ \\
\hline 9.2 & M: C & $\begin{array}{l}\mathrm{F}_{1,222}=3.023 \\
\mathrm{p}<.10\end{array}$ & $\begin{array}{l}\text { Hypothesis partially supported: } \\
\text { Product congruency has a statistically significant impact on } \\
\text { celebrity similarity at a p-value of .10. }\end{array}$ \\
\hline 9.3 & I: A*C & $\begin{array}{l}\mathrm{F}_{1,222}=.232 \\
\mathrm{p}>.05\end{array}$ & $\begin{array}{l}\text { Hypothesis not supported: } \\
\text { Together, celebrity endorsement authenticity and product } \\
\text { congruency have no statistically significant impact on } \\
\text { celebrity similarity. }\end{array}$ \\
\hline
\end{tabular}

\section{Interpretation}

When looking to evaluate whether customers feel similar to a given celebrity endorser, authenticity makes an impact and congruence makes a partial impact. This means that if brand managers were looking to increase feelings of similarity with customers, it would be best to select a celebrity that is authentic and a celebrity that is congruent with the product or product

\section{Celebrity Emotional Connection}

Results

When evaluating celebrity emotional connection, the overall model fit is significant $\left(F_{7,222}=8.667, p<.05\right)$. The hypothesis identification number, manipulation effect, ANOVA results and whether or not the hypothesis statement is supported is provided in the table below. 


\begin{tabular}{|c|l|l|l|}
\hline H & \multicolumn{1}{|c|}{ Effect } & \multicolumn{1}{|c|}{$\begin{array}{c}\text { ANOVA } \\
\text { Results }\end{array}$} & \multicolumn{1}{c|}{ Findings } \\
\hline 10.1 & $\mathrm{M}: \mathrm{A}$ & $\begin{array}{l}\mathrm{F}_{1,222}= \\
45.526 \\
\mathrm{p}<.05\end{array}$ & $\begin{array}{l}\text { Hypothesis supported: } \\
\text { Celebrity endorsement authenticity has a statistically } \\
\text { significant impact on celebrity emotional connection. }\end{array}$ \\
\hline 10.2 & $\mathrm{M}: \mathrm{C}$ & $\begin{array}{l}\mathrm{F}_{1,222}=.574 \\
\mathrm{p}>.05\end{array}$ & $\begin{array}{l}\text { Hypothesis not supported: } \\
\text { Product congruency has no statistically significant impact } \\
\text { on celebrity emotional connection. }\end{array}$ \\
\hline 10.3 & $\mathrm{I}: \mathrm{A}^{*} \mathrm{C}$ & $\begin{array}{l}\mathrm{F}_{1,222}=.091 \\
\mathrm{p}>.05\end{array}$ & $\begin{array}{l}\text { Hypothesis not supported: } \\
\text { Together, celebrity endorsement authenticity and product } \\
\text { congruency have no statistically significant impact on } \\
\text { celebrity emotional connection. }\end{array}$ \\
\hline $\mathrm{I}: \mathrm{C}^{*} \mathrm{G}$ & $\begin{array}{l}\mathrm{F}_{1,222}=3.159 \\
\mathrm{p}<.10\end{array}$ & $\begin{array}{l}\text { Together, product congruency and gender have a } \\
\text { statistically significant impact on celebrity emotional } \\
\text { connection at a p-value of .10. Emotional connection is } \\
\text { statistically higher for female endorsers than male } \\
\text { endorsers of congruent products, but not non-congruent } \\
\text { products. [See Emotional Connection } \\
\text { (Congruent*Gender)] }\end{array}$ \\
\hline & I: ${ }^{*} \mathrm{C}^{*} \mathrm{G}$ & $\begin{array}{l}\mathrm{F}_{1,222}=6.591 \\
\mathrm{p}<.05\end{array}$ & $\begin{array}{l}\text { The combination of celebrity endorsement authenticity, } \\
\text { product congruency and gender has a statistically } \\
\text { significant impact on celebrity emotional connection. [See } \\
\text { Emotional Connection (Authentic) and Emotional } \\
\text { Connection (Not Authentic)] }\end{array}$ \\
\hline
\end{tabular}
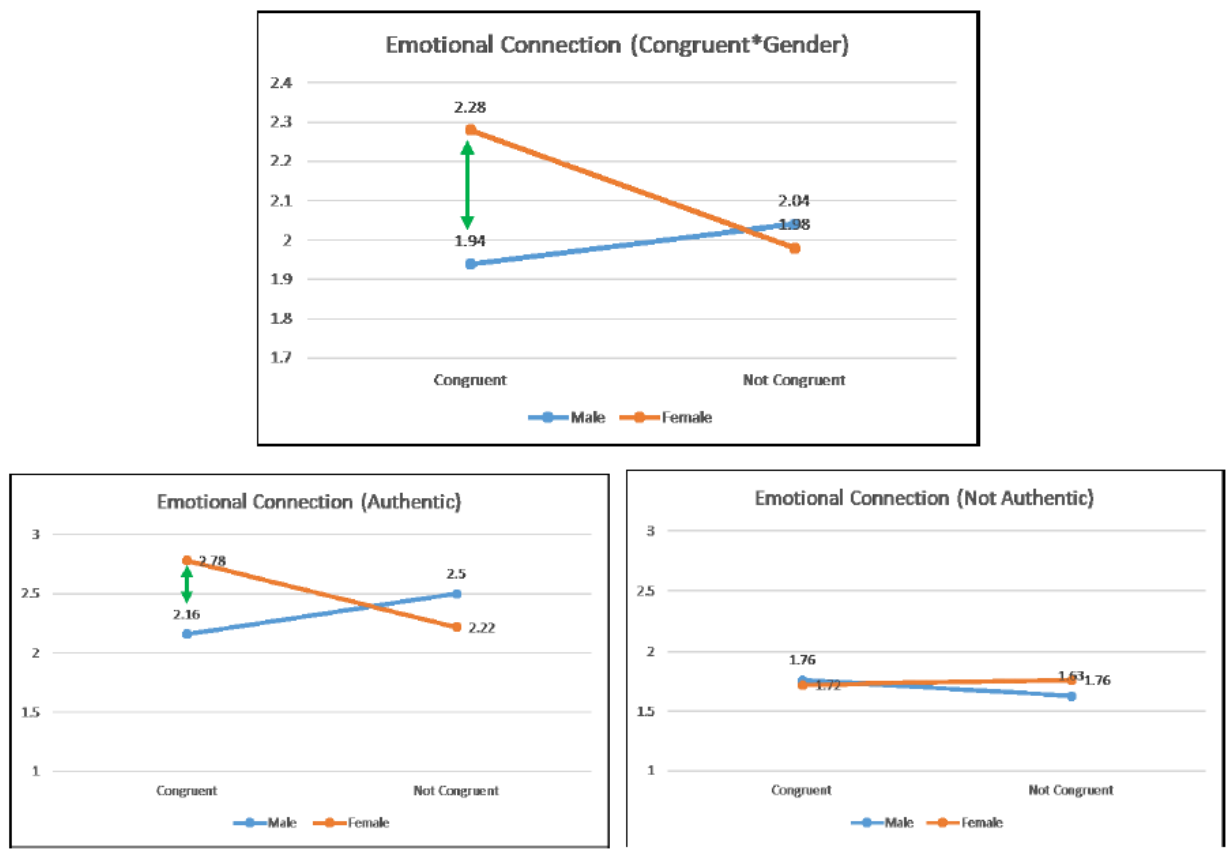

\section{Interpretation}

When looking to evaluate whether customers feel similar to a given celebrity endorser, authenticity makes an impact. This means that if brand managers were looking to increase feelings of emotional connection with a given endorser, it would be best to select a celebrity that is authentic than not authentic. There is not enough evidence to suggest respondents exposed to the salsa condition $(C)$ had a stronger emotional connection than those exposed to the toothpaste condition (NC). There is not strong enough evidence to suggest the combination of an authentic celebrity endorsing a congruent product, in this case salsa, has a significantly different effect on respondents' emotional connection to a given celebrity endorser from other combinations. Although not originally hypothesized ( $C^{*} G$ and 
$A * C * G)$, gender plays a role in a customer's emotional connection towards a celebrity endorser. Emotional connection was statistically higher when Chef Jane Smith (F) endorsed salsa compared to when Chef John Smith (M) endorsed salsa. This effect did not hold true for the endorsement of toothpaste. When adding the dimension of authenticity, this effect only held true when the endorser was described as authentic. This means that customers will have a stronger emotional connection to a female endorser if she endorses a congruent product and is deemed as authentic. If the endorser is authentic but not congruent with the brand's product, customers will have the same emotional connection to a male endorser as a female endorser.

\section{Brand Evaluation \\ Brand Loyalty \\ Results}

When evaluating brand loyalty, the overall model fit is significant $\left(F_{7,222}=2.822, p<.05\right)$. The hypothesis identification number, manipulation effect, ANOVA results and whether or not the hypothesis statement is supported is provided in the table below.

\begin{tabular}{|c|l|l|l|}
\hline H & Effect & \multicolumn{1}{|c|}{$\begin{array}{c}\text { ANOVA } \\
\text { Results }\end{array}$} & \multicolumn{1}{c|}{ Findings } \\
\hline 11.1 & M: A & $\begin{array}{l}\mathrm{F}_{1,222}=9.299 \\
\mathrm{p}<.05\end{array}$ & $\begin{array}{l}\text { Hypothesis supported: } \\
\text { Celebrity endorsement authenticity has a statistically } \\
\text { significant impact on brand loyalty. }\end{array}$ \\
\hline 11.2 & M: $\mathrm{C}$ & $\begin{array}{l}\mathrm{F}_{1,222}=8.278 \\
\mathrm{p}<.05\end{array}$ & $\begin{array}{l}\text { Hypothesis supported: } \\
\text { Product congruency has a statistically significant impact on } \\
\text { brand loyalty. }\end{array}$ \\
\hline 11.3 & $\mathrm{I}: \mathrm{A}^{*} \mathrm{C}$ & $\begin{array}{l}\mathrm{F}_{1,222}=.277 \\
\mathrm{p}>.05\end{array}$ & $\begin{array}{l}\text { Hypothesis not supported: } \\
\text { Together, celebrity endorsement authenticity and product } \\
\text { congruency have no statistically significant impact on brand } \\
\text { loyalty. }\end{array}$ \\
\hline
\end{tabular}

\section{Interpretation}

When looking to enhance brand loyalty, authenticity and congruence make an impact. This means that if brand managers were looking to enhance brand loyalty through endorsement, it would be better to select a celebrity that is authentic and a celebrity that is congruent with the product or product category. Although there is not strong enough evidence to suggest the combination of an authentic celebrity endorsing a congruent product, in this case salsa, has a significantly different effect on brand loyalty from other combinations, my hypothesis $\left(A^{\star} C\right)$ remains directionally supported.

\section{Willingness to Buy}

Results

When evaluating purchase intentions, the overall model fit is significant $\left(F_{7,222}=5.885, p<.05\right)$. The hypothesis identification number, manipulation effect, ANOVA results and whether or not the hypothesis statement is supported is provided in the table below. 


\begin{tabular}{|c|l|l|l|}
\hline H & Effect & \multicolumn{1}{|c|}{$\begin{array}{c}\text { ANOVA } \\
\text { Results }\end{array}$} & \multicolumn{1}{c|}{ Findings } \\
\hline 12.1 & M: A & $\begin{array}{l}\mathrm{F}_{1,222}=9.669 \\
\mathrm{p}<.05\end{array}$ & $\begin{array}{l}\text { Hypothesis supported: } \\
\text { Celebrity endorsement authenticity has a statistically } \\
\text { significant impact on purchase intentions. }\end{array}$ \\
\hline 12.2 & M: C & $\begin{array}{l}\mathrm{F}_{1,222}= \\
26.171 \\
\mathrm{p}<.05\end{array}$ & $\begin{array}{l}\text { Hypothesis supported: } \\
\text { Product congruency has a statistically significant impact on } \\
\text { purchase intentions. }\end{array}$ \\
\hline 12.3 & I: A*C & $\begin{array}{l}\mathrm{F}_{1,222}=.668 \\
\mathrm{p}>.05\end{array}$ & $\begin{array}{l}\text { Hypothesis not supported: } \\
\text { Together, celebrity endorsement authenticity and product } \\
\text { congruency have no statistically significant impact on } \\
\text { purchase intentions. }\end{array}$ \\
\hline
\end{tabular}

\section{Interpretation}

When looking at consumer willingness to buy, otherwise known as purchase intentions, authenticity and congruence make an impact. This means that if brand managers were looking to enhance purchase intentions through endorsement, it would be better to select a celebrity that is authentic and a celebrity that is congruent with the product or product category. Although there is not strong enough evidence to suggest the combination of an authentic celebrity endorsing a congruent product, in this case salsa, has a significantly different effect on purchase intentions from other combinations, my hypothesis $\left(A^{\star} C\right)$ remains directionally supported.

\section{Purchase at a Premium}

Results

When evaluating willingness to purchase at a premium, the overall model fit is significant $\left(F_{7,222}=5.302, p<.05\right)$. The hypothesis identification number, manipulation effect, ANOVA results and whether or not the hypothesis statement is supported is provided in the table below.

\begin{tabular}{|l|l|l|l|}
\hline H & \multicolumn{1}{|c|}{ Effect } & \multicolumn{1}{|c|}{$\begin{array}{c}\text { ANOVA } \\
\text { Results }\end{array}$} & \multicolumn{1}{c|}{ Findings } \\
\hline 13.1 & M: A & $\begin{array}{l}\mathrm{F}_{1,222}=8.066 \\
\mathrm{p}<.05\end{array}$ & $\begin{array}{l}\text { Hypothesis supported: } \\
\text { Celebrity endorsement authenticity has a statistically } \\
\text { significant impact on willingness to purchase at a premium }\end{array}$ \\
\hline 13.2 & $\mathrm{M}: \mathrm{C}$ & $\begin{array}{l}\mathrm{F}_{1,222}= \\
22.511 \\
\mathrm{p}<.05\end{array}$ & $\begin{array}{l}\text { Hypothesis supported: } \\
\text { Product congruency has a statistically significant impact on } \\
\text { willingness to purchase at a premium. }\end{array}$ \\
\hline 13.3 & $\mathrm{I}: \mathrm{A}^{*} \mathrm{C}$ & $\begin{array}{l}\mathrm{F}_{1,222}=1.110 \\
\mathrm{p}>.05\end{array}$ & $\begin{array}{l}\text { Hypothesis not supported: } \\
\text { Together, celebrity endorsement authenticity and product } \\
\text { congruency have no statistically significant impact on } \\
\text { willingness to purchase at a premium }\end{array}$ \\
\hline I: $\mathrm{A}^{*} \mathrm{C} * \mathrm{G}$ & $\begin{array}{l}\mathrm{F}_{1,222}=3.455 \\
\mathrm{p}<.10\end{array}$ & $\begin{array}{l}\text { The combination of celebrity endorsement authenticity, } \\
\text { product congruency and gender has a statistically } \\
\text { significant impact on willingness to purchase at a premium } \\
\text { at a p-value of .10. Willingness to buy a product at a } \\
\text { premium price is significantly higher when a female } \\
\text { endorser is authentic versus not authentic. There is not } \\
\text { significant difference for male endorsers. This effect only } \\
\text { holds true when endorsers are congruent with the product. } \\
\text { [See Purchase Premium (Congruent) and Purchase } \\
\text { Premium (Not Congruent)] }\end{array}$ \\
\hline
\end{tabular}




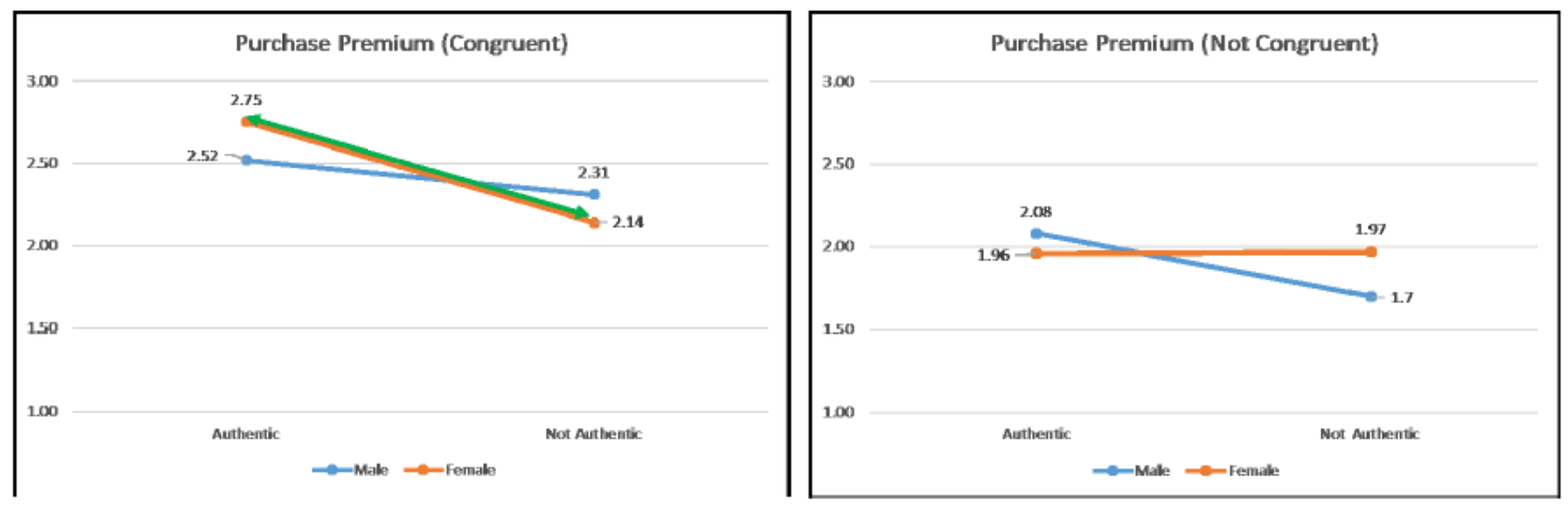

\section{Interpretation}

When looking to enhance consumer willingness to purchase at a premium, authenticity and congruence make an impact. This means that if brand managers were looking to enhance consumer willingness to buy the brand's product at a premium price through endorsement, it would be better to select a celebrity endorser that is authentic and a celebrity that is congruent with the product or product category. Although there is not strong enough evidence to suggest the combination of an authentic celebrity endorsing a congruent product, in this case salsa, has a significantly different effect on brand satisfaction from other combinations, my hypothesis $\left(A^{\star} C\right)$ remains directionally supported. Although not originally hypothesized $\left(A^{\star} C^{\star} G\right)$, gender plays a role in premium purchase intentions. Results showed that respondents exposed to Jane Smith $(F)$ endorsing salsa $(C)$ had significantly higher premium purchase intentions if she was described as authentic (A) versus not authentic (NA). Therefore, if a brand manager selects a female endorser that is also congruent with the brand product or product category, willingness to purchase at a premium would be greater if the endorser was also authentic.

\section{Overall Brand Satisfaction}

\section{Results}

When evaluating overall brand satisfaction, the overall model fit is significant $\left(F_{7,222}=5.614, p<.05\right)$. The hypothesis identification number, manipulation effect, ANOVA results and whether or not the hypothesis statement is supported is provided in the table below.

\begin{tabular}{|c|l|l|l|}
\hline H & Effect & \multicolumn{1}{|c|}{$\begin{array}{c}\text { ANOVA } \\
\text { Results }\end{array}$} & \multicolumn{1}{c|}{ Findings } \\
\hline 14.1 & M: A & $\begin{array}{l}\mathrm{F}_{1,222}= \\
22.036 \\
\mathrm{p}<.05\end{array}$ & $\begin{array}{l}\text { Hypothesis supported: } \\
\text { Celebrity endorsement authenticity has a statistically } \\
\text { significant impact on overall brand satisfaction. }\end{array}$ \\
\hline 14.2 & M: C & $\begin{array}{l}\mathrm{F}_{1,222}= \\
12.305\end{array}$ & $\begin{array}{l}\text { Hypothesis supported: } \\
\text { Product congruency has a statistically significant impact on } \\
\text { overall brand satisfaction. }\end{array}$ \\
\hline 14.3 & I: A*C & $\begin{array}{l}\mathrm{F}_{1,222}=.224 \\
\mathrm{p}>.05\end{array}$ & $\begin{array}{l}\text { Hypothesis not supported: } \\
\text { Together, celebrity endorsement authenticity and product } \\
\text { congruency have no statistically significant impact on overall } \\
\text { brand satisfaction. }\end{array}$ \\
\hline
\end{tabular}

\section{Interpretation}

When looking to enhance brand satisfaction, authenticity and congruence make an impact. This means that if brand managers were looking to enhance consumer satisfaction with the brand through endorsement, it would be 
better to select a celebrity endorser that is authentic and a celebrity that is congruent with the product or product category. Although there is not strong enough evidence to suggest that the combination of an authentic celebrity endorsing a congruent product, in this case salsa, has a significantly different effect on brand satisfaction from other combinations, my hypothesis $\left(A^{\star} C\right)$ remains directionally supported.

\section{Overall Brand Impression}

\section{Results}

When evaluating overall brand impression, the overall model fit is significant $\left(F_{7,222}=12.034, p<.05\right)$. The hypothesis identification number, manipulation effect, ANOVA results and whether or not the hypothesis statement is supported is provided in the table below.

\begin{tabular}{|c|l|l|l|}
\hline H & Effect & \multicolumn{1}{|c|}{$\begin{array}{c}\text { ANOVA } \\
\text { Results }\end{array}$} & \multicolumn{1}{c|}{ Findings } \\
\hline 15.1 & M: A & $\begin{array}{l}\mathrm{F}_{1,222}= \\
60.969 \\
\mathrm{p}<.05\end{array}$ & $\begin{array}{l}\text { Hypothesis supported: } \\
\text { Celebrity endorsement authenticity has a statistically } \\
\text { significant impact on overall brand impression. }\end{array}$ \\
\hline 15.2 & M: C & $\begin{array}{l}\mathrm{F}_{1,222}= \\
14.048 \\
\mathrm{p}<.05\end{array}$ & $\begin{array}{l}\text { Hypothesis supported: } \\
\text { Product congruency has a statistically significant impact on } \\
\text { overall brand impression. }\end{array}$ \\
\hline 15.3 & I: $\mathrm{A}^{*} \mathrm{C}$ & $\begin{array}{l}\mathrm{F}_{1,222}=1.921 \\
\mathrm{p}>.05\end{array}$ & $\begin{array}{l}\text { Hypothesis not supported: } \\
\text { Together, celebrity endorsement authenticity and product } \\
\text { congruency have no statistically significant impact on } \\
\text { overall brand impression. }\end{array}$ \\
\hline I: A* $\mathrm{C}^{*} \mathrm{G}$ & $\begin{array}{l}\mathrm{F}_{1,222}=4.488 \\
\mathrm{p}<.05\end{array}$ & $\begin{array}{l}\text { The combination of celebrity endorsement authenticity, } \\
\text { product congruency and gender has a statistically significant } \\
\text { impact on overall brand impression at a .05 significance } \\
\text { level. Female endorsers provide significantly greater brand } \\
\text { impressions when congruent with the product versus not } \\
\text { congruent. This only holds true when the female endorser is } \\
\text { authentic. Male endorsers provide significantly greater } \\
\text { brand impressions when congruent with the product versus } \\
\text { not congruent. This holds true for male endorsers both when } \\
\text { they are deemed authentic and not authentic. [See Brand } \\
\text { Impressions }(A) \text { and Brand Impressions (NA)]. }\end{array}$ \\
\hline
\end{tabular}

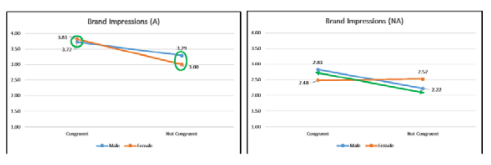

When looking to enhance brand impressions, authenticity and congruence make an impact. This means that if brand managers were looking to enhance consumer impressions of the brand through endorsement, it would be better to select a celebrity endorser that is authentic and a celebrity that is congruent with the product or product category. Although there is not strong enough evidence to suggest that the combination of an authentic celebrity endorsing a congruent product, in this case salsa, has a significantly different effect on brand satisfaction from other combinations, my hypothesis $\left(A^{\star} C\right)$ is directionally supported. Although not originally hypothesized $\left(A^{\star} C{ }^{\star} G\right)$, gender plays a role in brand impressions. Results showed that respondents exposed to Jane Smith (F) who was described as authentic had significantly higher brand impressions of Brand $X$ if she was congruent (C) versus not congruent (NC) with the product. Therefore, if a brand manager selects a female endorser that is authentic, brand impressions would be greater if the endorser was also congruent with the brand product or product category. Results also showed that respondents exposed to John Smith (M) had significantly higher brand impressions of Brand $X$ if he was congruent (C) versus not congruent (NC) with the product. This effect held true both when John Smith was described as authentic and not authentic. Therefore, if a brand manager selects a male endorser, brand impressions would be greater if the endorser was congruent versus not congruent with the product, no matter if the endorser was authentic or not. 


\section{Conclusions and Implications}

\begin{tabular}{|c|l|}
\hline Symbol & \multicolumn{1}{|c|}{ Interpretation } \\
\hline $\mathbf{X}$ & Hypothesis is significantly supported. \\
\hline $\mathbf{X}$ & Hypothesis is marginally supported. \\
\hline $\mathbf{X}$ & Hypothesis is not supported. \\
\hline
\end{tabular}

\section{Brand Experience}

\begin{tabular}{|l|c|c|c|}
\hline Brand Experience Variable & M: Authentic & M: Congruence & I: Authentic*Conguent \\
\hline Sensory & $\mathbf{X}$ & $\mathbf{X}$ & $\mathbf{X}$ \\
\hline Affective & $\mathbf{X}$ & $\mathbf{X}$ & $\mathbf{X}$ \\
\hline Cognitive & $\mathbf{X}$ & $\mathbf{X}$ & $\mathbf{X}$ \\
\hline Behavioral & $\mathbf{X}$ & $\mathbf{X}$ & $\mathbf{X}$ \\
\hline Relational & $\mathbf{X}$ & $\mathbf{X}$ & $\mathbf{X}$ \\
\hline
\end{tabular}

*Variables in which gender had an interaction effect: Sensory Brand Experience

In summary, the results of this study suggest that authenticity and product congruence independently enhance sensory, affective, and relational experience but not the behavioral or cognitive experiences a consumer has with a brand. This suggests that authenticity and congruence remain important when emotional attachment or an attachment that doesn't involve explicit action or thought with a brand is involved. Therefore, celebrity endorsers that are authentic and congruent have an implicit, emotional impact on consumers, but this implicit connection isn't enough for consumers to engage in explicit behavioral or thoughtful experiences with the brand. Although not hypothesized, gender had an impact on sensory brand experience. Particularly, when the celebrity endorser was authentic and congruent, the female endorser scored higher when evaluating sensory brand experience. Hence, if a company is looking to enhance sensory brand experience they may also want to consider hiring a female endorser, especially if their endorser has already been identified as authentic and congruent.

\section{Celebrity Evalutations}

\begin{tabular}{|l|c|c|c|}
\hline Celebrity Evaluation Variable & M: Authentic & M: Conguence & I: Authentic*Conguent \\
\hline Celebrity Loyalty & $\mathbf{X}$ & $\mathbf{X}$ & $\mathbf{X}$ \\
\hline Celebrity Similarity & $\mathbf{X}$ & $\mathbf{X}$ & $\mathbf{X}$ \\
\hline Emotional Connection & $\mathbf{X}$ & $\mathbf{X}$ & $\mathbf{X}$ \\
\hline Positive Word of Mouth & $\mathbf{X}$ & $\mathbf{X}$ & $\mathbf{X}$ \\
\hline Overall Celebrity Impression & $\mathbf{X}$ & $\mathbf{X}$ & $\mathbf{X}$ \\
\hline
\end{tabular}

*Variables in which gender had an interaction effect: Celebrity Loyalty, Celebrity Emotional Connection, Positive Word of Mouth, Overall Celebrity Impressions

Celebrity evaluations are extremely important for brands to consider in endorsement as, by definition, the relationship between the consumer and celebrity directly impacts the attributes a consumer associates with a brand. Overall, results demonstrate that authenticity is the most important factor when consumers are evaluating their loyalty, similarity, emotional connection to and overall impression of the celebrity as well as when evaluating their likelihood to recommend the celebrity to others. This makes sense as authenticity is a well-received and often times praised personality characteristic associated with a given person. Congruent products had a significant effect on positive word of mouth and overall celebrity impressions but didn't matter when it came to a consumer's feelings of loyalty, similarity or emotional connection with a celebrity. This suggests that if a company were to consider 
enhancing the positive word of mouth and impressions of their endorsers, they should look at congruence as a factor but it's not a significant factor for the other variables. Although not hypothesized, gender plays a significant role in the relationship between the consumer and the celebrity for four out of five dependent variables measuring celebrity evaluations. In particular, if both deemed authentic and congruent, women endorsers produce the strongest results. This suggests that if brands are looking to enhance connections between endorsers and customers, it may be better to have a female endorser.

\section{Brand Evalutations}

\begin{tabular}{|l|c|c|c|}
\hline Brand Evaluation Variable & M: Authentic & M: Congruence & I: Authentic*Congruent \\
\hline Purchase Intentions & $\mathbf{X}$ & $\mathbf{X}$ & $\mathbf{X}$ \\
\hline Purchase at Premium & $\mathbf{X}$ & $\mathbf{X}$ & $\mathbf{X}$ \\
\hline Brand Loyalty & $\mathbf{X}$ & $\mathbf{X}$ & $\mathbf{X}$ \\
\hline Overall Brand Impression & $\mathbf{X}$ & $\mathbf{X}$ & $\mathbf{X}$ \\
\hline Overall Brand Satisfaction & $\mathbf{X}$ & $\mathbf{X}$ & $\mathbf{X}$ \\
\hline
\end{tabular}

*Variables in which gender had an interaction effect: Purchase at Premium, Overall Brand Impression

Lastly, overall brand evaluations showed consistent results in which the best brand evaluations resulted from a celebrity endorser that was authentic and was congruent with the product or product category. For companies and company brand management, this means it is in their best interest to select an endorsement candidate that is both authentic and congruent when looking to enhance overall brand evaluations such as purchase intentions, premium purchase intentions, brand loyalty, overall brand impressions and brand satisfaction. Gender had an impact when evaluating premium purchase intentions and overall brand impression. Premium purchase likelihood and overall impressions were higher for authentic female endorsers of congruent products. Therefore, if a company is looking to increase pricing or enhance overall brand impressions, it may be in their best interest to hire a female endorser, given she is authentic and aligned with the product or product category.

\section{Implications Academic Research Implications}

This study confirms prior research regarding celebrity endorser authenticity and product congruence. Previous studies demonstrate that authenticity produces positive word of mouth as well as purchase intentions (Kowalczyk \& Pounders, 2016). This study aligns with this phenomenon. Additionally, it supports the match-up hypothesis that suggests congruence between a celebrity and a product is effective in building brand satisfaction, similarity, brand recall, purchase intentions and attitudes (Kahle \& Homer, 1985). This study aligns with the match-up hypothesis in all variables measuring overall brand evaluations: brand loyalty, purchase intentions, premium purchase intentions, brand impressions and brand satisfaction.

This study differs from previous research as it analyzes the constructs of congruence and authenticity interdependently. Results show there is no synergistic effect between congruence and authenticity but directionally, the highest means came from those exposed to authentic and congruent endorsement. This is significant for further research as it puts into question what other antecedents need to be present in order to create synergy between authenticity and congruence or whether these two constructs are simply not associated and rather coincidently move in the same direction.

This study also differs from previous research as it measures how these constructs impact brand experience. This is an increasingly important aspect for researchers to observe as customers are demanding more relational, direct experiences from marketers (Kotler et al, 2016). Previous studies regarding co-creation have observed brand 
experience but no previous studies have looked at a celebrity endorser's impact on enhancing brand experience. Results demonstrate that, independently, authentic and congruent celebrity endorsement has a significant impact on sensory, affective and relational brand experience. Therefore, people have a stronger sensory, emotional and relational connection with brands when endorsers are authentic and congruent with the product or product category. This calls into question how brand experience can be further leveraged using endorsement as a marketing technique.

\section{Practical Implications}

This study can be applicable in two contexts for companies and company brand management: when initiating a new endorsement campaign or agreement and when evaluating the effectiveness of their current endorsement campaigns or agreements.

When initiating a new endorsement campaign, these results suggest companies should measure how authentic and how congruent customers perceive the celebrity up for consideration before officially hiring them. They can do so by surveying a sample of customers on the subcomponents of rarity and stability (Moulard et al. 2015) and asking how well the celebrity and brand "match" (Kahle \& Homer, 1985). This would allow brand managers to better estimate how much they can rely on the endorser to boost brand evaluations or brand experience. This will also help them predict how strong customers' personal associations with the celebrity are. These associations are important as people often compare celebrities to their aspirational selves so how connected customers feel to a celebrity is an important predictor for how brands can build self-congruence with customers (Jamal \& Goode, 2001).

When evaluating current endorsement deals, these results suggest companies should do their best to enhance the perceived authenticity of their current endorsers and clearly demonstrate how the celebrity relates to the brand's product itself. In order to enhance perceived authenticity, a company should emphasize that the celebrity is rare, or carries unique qualities and talents, and is stable, or is consistent with their values over time. They can do so by featuring the celebrity's past experiences over the years as well as highlight any awards or special recognition the endorser may receive in promotional campaigns. In order to clarify product congruence, brands should feature the celebrity actively using the product and, if appropriate, actively using the product while showcasing their unique talents either professionally or personally.

In both contexts, however, the same overarching takeaway remains: marketers must think beyond a celebrity's title and consider who they are as people and how the public perceives them as people, not only as professionals. We remain in an era of transparency, connectedness and access. It is in the best interest of marketers to take the time to research the deeper values and personality attributes of celebrities and how they demonstrate this over time. If an endorser is able to remain consistent to their values, it will provide a more consistent brand experience for customers.

\section{Limitations and Future Directions}

The main problem I faced when conducting this study was a relatively homogenous sample. My sample of respondents was limited to undergraduate students taking an introductory marketing course in the Neeley School of Business at Texas Christian University. Because Texas Christian University has a relatively homogeneous undergraduate population, the sample was limited to primarily Caucasian individuals, a younger age category, and those of similar income levels and educational backgrounds. Further studies using a larger and more diverse sample could further enlighten this phenomenon. 
This study inspires five more dimensions of research to be explored. First, it calls into question whether these results would remain consistent for other demographic categories such as age or income level. Any differences could more fully explain a consumer's decision-making process and whether authenticity matters for all segments or only the select group observed here. Second, a future study would be crucial to proving external validity. If a study were to demonstrate that these constructs hold true when using real celebrities, brands could more clearly apply the concepts to practice. Third, this study only observed low involvement products-salsa and toothpaste. It would be interesting for a future study to replicate the procedures with a high involvement product and see if they hold the same, are diminished, or enhanced. Fourth, although gender was used as a control variable, there were significant effects between male and female endorsers, especially when consumers evaluated celebrities themselves. A study that observes underlying psychological constructs associated with gender, such as attraction, and how they play a role in this phenomenon would be extremely interesting and further the field of both marketing and psychology. Lastly, a further study could observe if these results hold true or are amplified when endorsement is not explicit and when the celebrity is less traditional. Micro-celebrities, often times known as influencers, are becoming popular candidates for endorsement in marketing today. A further study could observe whether authenticity and congruence impact influencer endorsement in the same way as traditional endorsement practices.

Overall, this study illuminates a few key insights that further the field of marketing. First, authenticity matters. Our world is interconnected, and customers demand authentic experiences from both celebrities they look up to and the brands these celebrities endorse. Second, the match-up hypothesis still holds true. This study demonstrates that endorsement deals perform better when the celebrity is congruent with the product or product category. However, this phenomenon has altered in the sense that although a celebrity's profession may not be congruent with the product, their personal interests may be. Due to social media, consumers now have access to personal information about celebrities which gives brands significantly more opportunities to use congruence to their advantage. Lastly, it is important for companies to recognize that, overall, celebrity endorsement is no longer black and white, and deeper personality traits beyond profession should be considered and monitored in endorsement agreements. Although this may cause more effort, if brands do their due diligence, they will be able to maintain endorsement relationships that are consistent, well-received, and in the long-term significantly more effective. 


\section{Appendix and Works Cited}

Booth N, Matic JA. Mapping and leveraging influencers in social media to shape corporate brand perceptions. Corporate Communications: An International Journal. 2011;16(3):184-191.

Brakus J, Schmitt B, Zarantonello L. Brand experience: What is it? how is it measured? does it affect loyalty? Journal of Marketing. 2009;73(3):52-68.

Cialdini R. Influence: The psychology of persuasion. Revised ed. Harper Business; 2006.

Choi SM, Rifon NJ. It is a match: The impact of congruence between celebrity image and consumer ideal self on endorsement effectiveness. Psychology \& Marketing. 2012;29(9):639-650.

Darley J, Latane, B. Bystander effect or bystander apathy, 1968; 2017:636-637.

Friedman H, Friedman L. Endorser effectiveness by product type. Journal of Advertising Research. 1979;19(5):63-71.

Grayson K, Martinec R. Consumer perceptions of iconicity and indexicality and their influence on assessments of authentic market offerings. Journal of Consumer Research. 2004;31(2):296-312.

Harding LM, Humphreys A. Self-brand attraction: An interpersonal attraction approach to brand relationships. Advances in Consumer Research. 2010;37:809-810.

Hilton World. Paris Hilton Carl's Jr Commercial in 2005. [YouTube]. ; 2015.

Ilicic J. Being true to oneself. Psychology \& marketing. 2016;33(6):410-420.

Jamal A, Goode MMH. Consumers and brands: A study of the impact of self-image congruence on brand preference and satisfaction. Marketing Intelligence \& Planning. 2001;19(7):482-492.

Kahle L, Homer P. Physical attractiveness of the celebrity endorser: A social adaptation perspective. Journal of Consumer Research. 1985;11(4):954-961.

Kelting K, Rice DH. Should we hire David Beckham to endorse our brand? Contextual interference and consumer memory for brands in a celebrity's endorsement portfolio. Psychology \& Marketing. 2013;30(7):602-613.

Kotler P., Kartajaya H., Setiawan I. Marketing 4.0. US: John Wiley \& Sons Inc; 2016.

Kowalczyk CM, Pounders KR. Transforming celebrities through social media: The role of authenticity and emotional attachment. Journal of Product \& Brand Management. 2016;25(4):345-356.

Misra S, Beatty SE. Celebrity spokesperson and brand congruence: An assessment of recall and affect. Journal of Business Research. 1990;21(2):159-173.

Moulard JG, Popp Garrity C, Hamilton Rice D. What makes a human brand authentic? Psychology \& marketing. 2015;32(2):173-186. 
Nysveen H, Pedersen PE. Influences of co-creation on brand experience: The role of brand engagement. International Journal of Market Research. 2014;56(6):807.

Ohanian R. The impact of celebrity spokespersons' perceived image on consumers' intention to purchase. Journal of Advertising Research. 1991;31(1):46.

Pradhan D, Duraipandian I, Sethi D. Celebrity endorsement: How celebrity-brand-user personality congruence affects brand attitude and purchase intention. Journal of Marketing Communications. 2016;22(5):456-473.

Raluca, C. Celebrity endorsement strategy. Analele Universităţii Constantin Brâncuşi din Târgu Jiu : Seria Economie. 2012;3(3):75-79.

Turcotte J, York C, Irving J, Scholl RM, Pingree RJ. News recommendations from social media opinion leaders: Effects on media trust and information seeking. Journal of Computer-Mediated Communication. 2015;20(5):520-535.

\section{Scenario Descriptions}

Chef Photos
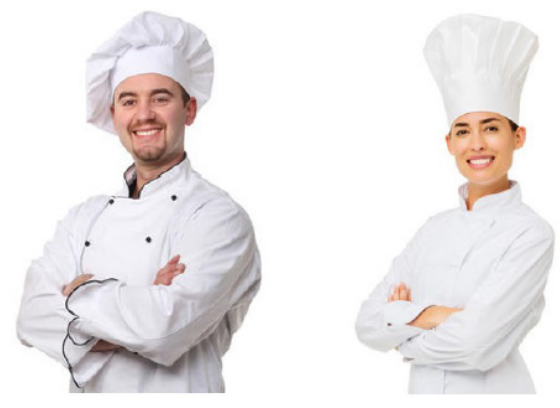

\section{Celebrity Status Descriptions}

"John Smith is a famous chef. He has been in the industry for over 20 years. He has his own featured program on a popular television network and has been featured as a celebrity judge on multiple cook-off television shows. He owns multiple restaurants across the United States that specialize in Mexican cuisine."

"Jane Smith is a famous chef. She has been in the industry for over 20 years. She has her own featured program on a popular television network and has been featured as a celebrity judge on multiple cook-off television shows. She owns multiple restaurants across the United States that specialize in Mexican cuisine."

\section{Authenticity Manipulation}

\section{Authentic Description:}

"He is often described as unique in his ways and stands out from others. He prefers to stay out of the spotlight when not working and keeps his private life, private. Most would say he hasn't changed much throughout his career. He is known for being straightforward, honest and staying out of trouble. He acts in a manner that is consistent with his values and rarely comes off as fake. He cares about openness and honesty in relationships and wants people to see the real him rather than his public image." 
"She is often described as unique in her ways and stands out from others. She prefers to stay out of the spotlight when not working and keeps her private life, private. Most would say she hasn't changed much throughout her career. She is known for being straightforward, honest and staying out of trouble. She acts in a manner that is consistent with her values and rarely comes off as fake. She cares about openness and honesty in relationships and wants people to see the real her rather than her public image."

\section{Inauthentic Description:}

"He is often described as generic in his ways and doesn't stand out from other professional chefs. He prefers to stay in the spotlight even when not working and makes his private life public. Most people would say he has changed a lot throughout his career. He is known for being indirect, dishonest and has been in and out of trouble. He acts in a manner that is inconsistent with his values and often comes off as being fake. He does not care about openness and honesty in relationships and wants people to see his public image rather than his real self."

"She is often described as generic in her ways and doesn't stand out from other professional chefs. She prefers to stay in the spotlight even when not working and makes her private life, public. Most people would say she has changed a lot throughout her career. She is known for being indirect, dishonest and has been in and out of trouble. She acts in a manner that is inconsistent with her values and often comes off as being fake. She does not care about openness and honesty in relationships and wants people to see her public image rather than her real self."

\section{Congruence Manipulation}

\section{Congruent Product:}

\section{Not Congruent Product:}

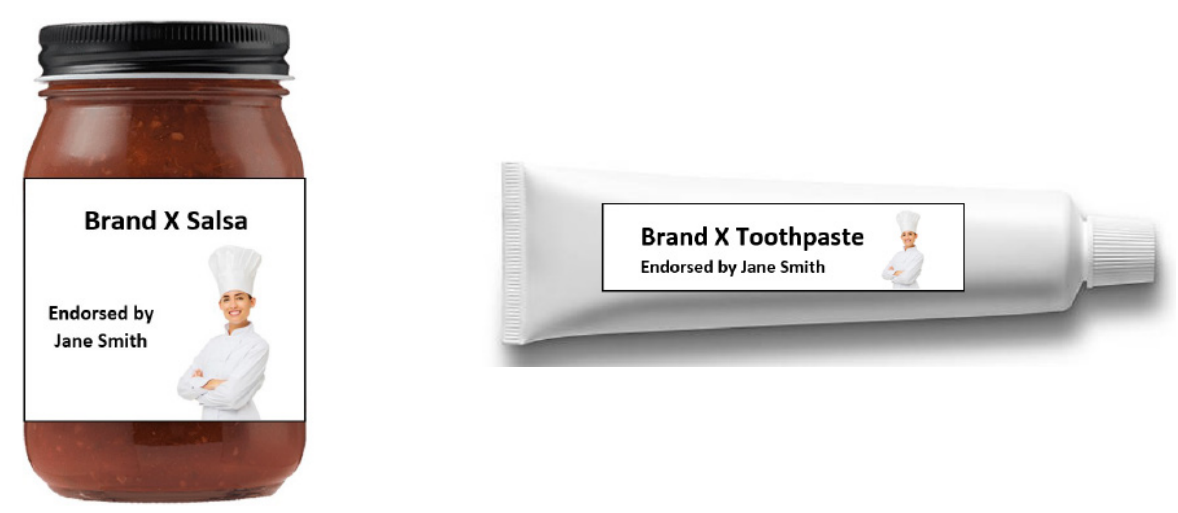

Dependant Variable Statements

Brand Experience:

\section{Sensory:}

- The brand makes a strong impression on my senses

- Being a customer of the brand gives me interesting sensory experiences

- The brand appeals strongly to my senses 
Affective:

- The brand induces my feelings

- I have strong emotions for the brand

- The brand often strongly engages me emotionally

\section{Cognitive:}

- I engage in a lot of thinking as a customer of the brand

- Being a customer of the brand stimulates my thinking and problem solving

- The brand often challenges my way of thinking

\section{Behavioral:}

- I often engage in action and behavior when I use the brand's services

- As a customer of the brand, I am rarely passive

- The brand activates me

\section{Relational:}

- As a customer of the brand, I feel like I am a part of a community

- I feel like I am a part of the brand's family

- As a customer of the brand, I never felt left alone

\section{Brand Evalutions}

\section{Purchase Intention:}

- I would buy this product

Purchase at a Premium:

- I would buy this product at a premium

\section{Brand Loyalty:}

- I feel loyalty towards this brand

\section{Overall Brand Impressions:}

- Overall, I have a positive impression of the brand

\section{Overall Brand Satisfaction:}

- $\quad$ Overall, I am satisfied with the brand

\section{Loyalty:}

- I feel loyalty towards this celebrity

Similarity:

- The celebrity is similar to me 


\section{Emotional Connection:}

- I feel emotionally connected to the celebrity

Positive WOM:

- I would recommend this celebrity to others

- I would speak favorably of this celebrity

Overall Celebrity Impressions:

- Overall, I have a positive impression of this celebrity 